\title{
The Neuropeptide VGF Is Reduced in Human Bipolar Postmortem Brain and Contributes to Some of the Behavioral and Molecular Effects of Lithium
}

\author{
Smita Thakker-Varia, ${ }^{1}$ Ying Y. Jean, ${ }^{1}$ Payal Parikh, ${ }^{1}$ Caroline F. Sizer, ${ }^{1}$ Jennifer Jernstedt Ayer, ${ }^{1}$ Ankit Parikh, ${ }^{1}$ \\ Thomas M. Hyde, ${ }^{2}$ Steven Buyske, ${ }^{3}$ and Janet Alder ${ }^{1}$ \\ ${ }^{1}$ Department of Neuroscience and Cell Biology, University of Medicine and Dentistry of New Jersey, Robert Wood Johnson Medical School, Piscataway, \\ New Jersey 08854, ${ }^{2}$ National Institute of Mental Health, Section on Neuropathology, Clinical Brain Disorders Branch, Bethesda, Maryland 20892, and \\ ${ }^{3}$ Department of Statistics, Rutgers University, Piscataway, New Jersey 08854
}

Recent studies demonstrate that the neuropeptide VGF (nonacronymic) is regulated in the hippocampus by antidepressant therapies and animal models of depression and that acute VGF treatment has antidepressant-like activity in animal paradigms. However, the role of VGF in human psychiatric disorders is unknown. We now demonstrate using in situ hybridization that VGF is downregulated in bipolar disorder in the CA region of the hippocampus and Brodmann's area 9 of the prefrontal cortex. The mechanism of VGF in relation to LiCl was explored. Both LiCl intraperitoneally and VGF intracerebroventricularly reduced latency to drink in novelty-induced hypophagia, and $\mathrm{LiCl}$ was not effective in $\mathrm{VGF}^{+/-}$mice, suggesting that VGF may contribute to the effects of $\mathrm{LiCl}$ in this behavioral procedure that responds to chronic antidepressant treatment. VGF by intrahippocampal injection also had novel activity in an amphetamine-induced hyperlocomotion assay, thus mimicking the actions of $\mathrm{LiCl}$ injected intraperitoneally in a system that phenocopies manic-like behavior. Moreover, $V G F^{+/-}$mice exhibited increased locomotion after amphetamine treatment and did not respond to LiCl, suggesting that $V G F$ is required for the effects of $\mathrm{LiCl}$ in curbing the response to amphetamine. Finally, VGF delivered intracerebroventricularly in vivo activated the same signaling pathways as $\mathrm{LiCl}$ and is necessary for the induction of mitogen-activated protein kinase and $\mathrm{Akt}$ by $\mathrm{LiCl}$, thus lending insight into the molecular mechanisms underlying the actions of VGF. The dysregulation of VGF in bipolar disorder as well as the behavioral effects of the neuropeptide similar to LiCl suggests that VGF may underlie the pathophysiology of bipolar disorder.

\section{Introduction}

VGF (nonacronymic), a secreted neuropeptide, has antidepressantlike actions in rodents (Hunsberger et al., 2007; Thakker-Varia et al., 2007). However, the significance and role of VGF in human psychiatric disorders remains to be elucidated. VGF is upregulated in the rodent hippocampus by manipulations that have antidepressant-like activity, such as electroconvulsive shock (Newton et al., 2003; Altar et al., 2004), imipramine, serotonin (Thakker-Varia et al., 2007), exercise (Hunsberger et al., 2007), and brain-derived neurotrophic factor (Bonni et al., 1995; Eagleson et al., 2001; Alder et al., 2003) treatments. Conversely, VGF expression is downregulated in the hippocampi of animals sub-

Received Nov. 11, 2009; revised May 21, 2010; accepted May 26, 2010.

This work was funded by a grant from the National Alliance for Research on Schizophrenia and Depression and the Foundation of the University of Medicine and Dentistry of New Jersey. We thank Sujata Kumar for help with silver grain counting of the frontal cortex, Dr. Chung-Lin Chang (Senior Veterinarian) for necropsy of LiCl-treated mice, and Michael Ansonoff for assistance with repeated-measures ANOVA. VGF ${ }^{+/-}$mice were generated by Regeneron and provided by Dr. Steve Salton. Postmortem tissue was provided from the brain collection of the Stanley Medical Research Institute, courtesy of Drs. Michael B. Knable, E. Fuller Torrey, Maree J. Webster, Serge Weis, and Robert H. Yolken.

Correspondence should be addressed to Dr. Janet Alder, Department of Neuroscience and Cell Biology, University of Medicine and Dentistry of New Jersey, Robert Wood Johnson Medical School, 675 Hoes Lane West, Robert Wood Johnson-School of Public Health 357A, NJ 08854-5635. E-mail: alderja@umdnj.edu.

DOI:10.1523/JNEUROSCI.5987-09.2010

Copyright $\odot 2010$ the authors $\quad 0270-6474 / 10 / 309368-13 \$ 15.00 / 0$ jected to models of depression (Thakker-Varia et al., 2007) and prenatal stress (Cattaneo et al., 2010).

The receptor for VGF has not been identified, but genetic ablation of VGF has yielded insight into the function of this neuropeptide. $V G F^{+/-}$mice have no gross abnormalities in brain morphology and display no differences in normal anxiety levels. However, VGF mutant mice do exhibit deficits in models of antidepressant-like activity (Hunsberger et al., 2007). Thus, VGF appears to be required for normal behavioral response in depression paradigms, suggesting that reduced VGF levels in humans may be associated with psychiatric disorders.

A recent study reports the downregulation of VGF in leukocytes of depressed patients, which is rescued by antidepressant treatment (Cattaneo et al., 2010). However, the expression levels of VGF in human CNS are not well characterized. Both the hippocampus and dorsolateral prefrontal cortex (DLPFC) have been implicated in the structural and functional deficits associated with psychiatric disorders on the basis of neuroimaging, neuropsychology, and postmortem neuropathology studies (Dickstein et al., 2005; Nakatani et al., 2006; Altshuler et al., 2008; Bonilha et al., 2008; Melcher et al., 2008; Koenigsberg et al., 2009). Specifically, mood disorders are correlated with smaller volumes and altered metabolic activity in these regions (Sheline et al., 1996; Mayberg et al., 2000; Drevets, 2001; Manji and Duman, 2001; Videbech and Ravnkilde, 2004; Fusar-Poli et al., 2007). There is 
Table 1. Stanley Foundation Neuropathology Consortium subject diagnostic groups and demographics

\begin{tabular}{|c|c|c|c|c|}
\hline Factor & Normal & Schizophrenia & Bipolar disorder & Major depression \\
\hline Age (years) & $48.1(29-68)$ & $44.5(25-62)$ & $42.3(25-61)$ & $46.5(30-65)$ \\
\hline Brain pH & $6.3(5.8-6.6)$ & $6.2(5.8-6.6)$ & $6.2(5.8-6.5)$ & $6.2(5.8-6.5)$ \\
\hline PMI (h) & $23.7(8-42)$ & $33.7(12-61)$ & $32.5(13-62)$ & $27.5(7-47)$ \\
\hline Gender & $9 \mathrm{M}, 6 \mathrm{~F}$ & $9 \mathrm{M}, 6 \mathrm{~F}$ & $9 \mathrm{M}, 6 \mathrm{~F}$ & $9 \mathrm{M}, 6 \mathrm{~F}$ \\
\hline Side of brain & $7 \mathrm{R}, 8 \mathrm{~L}$ & $6 \mathrm{R}, 9 \mathrm{~L}$ & $8 \mathrm{R}, 7 \mathrm{~L}$ & $6 \mathrm{R}, 9 \mathrm{~L}$ \\
\hline $\begin{array}{c}\text { Antipsychotic } \\
\text { exposure }\end{array}$ & NA & $5.2(0-20)$ & $2.1(0-6)$ & NA \\
\hline
\end{tabular}

For continuous variables (i.e. age, brain $\mathrm{pH}, \mathrm{PMI}$, and antipsychotic exposure), means are shown with ranges in parentheses. AP, antipsychotic; F-mg-Eq, fluphenazine milligram equivalents; $M$, male; $F$, female; $R$, right; $L$, left; NA, not applicable. Hippocampus and DLPFC tissues were derived from the Stanley Consortium, which consists of four diagnostic groups: nonpsychiatric controls $(n=15)$, schizophrenia $(n=15)$, bipolar disorder $(n=15)$, and major depression $(n=15)$. Diagnoses were performed independently by two psychiatrists according to the Diagnostic and Statistical Manual of Mental Disorders (fourth edition) criteria, and antipsychotic exposure was determined as an estimate of lifetime antipsychotic medication intake ( $\times 10^{4}$ fluphenazine milligram equivalents). The groups did not statistically differ according to age, $\mathrm{pH}$, or PMI and have been described previously (Torrey et al., 2000). Experiments were performed without knowledge of subject diagnoses, and diagnostic information was provided only after attainment of results.

one report of increased VGF protein expression in the DLPFC of four schizophrenia postmortem brains and of an increase in a specific VGF N-terminal peptide in the CSF of patients with schizophrenia as well as in a few major depressive disorder subjects (Huang et al., 2006). In contrast, results from the Stanley Medical Research Institute (SMRI) Genomics Database using the Array Collection indicate that VGF mRNA is decreased in the DLPFC of bipolar disorder and schizophrenia patients. Although these studies suggest the neuropsychiatric relevance of VGF, they are somewhat inconclusive and do not investigate the functional role of VGF in mood disorders.

Here we examine the pattern and levels of VGF mRNA expression in the hippocampus and DLPFC of postmortem samples of control, depression, bipolar disorder, and schizophrenia patients. Our findings indicate that $V G F$ is downregulated in human bipolar disorder in the CA region of the hippocampus and Brodmann's area 9 (BA9) of the DLPFC. Importantly, the studies in this report suggest novel and critical behavioral effects of VGF that mimic the actions of lithium and may contribute to some of the effects of lithium in models of bipolar disorder.

\section{Materials and Methods}

In situ hybridization. cDNA corresponding to human VGF gene (base pairs 1710-2160, Y12661) was subcloned into pCR4-TOPO and used to synthesize riboprobes with $\left[{ }^{35} \mathrm{~S}\right] \mathrm{UTP}$ (GE Healthcare) using an in vitro transcription kit (Promega). T7 and T3 polymerase were used to generate antisense and sense strand synthesis, respectively (specific activity of $\sim 1.9 \times 10^{9} \mathrm{cpm} / \mu \mathrm{g}$ ). The riboprobes were precipitated by ethanol, and the probe concentration was adjusted to $5 \mathrm{ng} / \mathrm{ml}$ in the hybridization buffer. Slide-mounted frozen coronal sections from the midhippocampus and DLFPC were obtained from the Stanley Foundation Neuropathology Consortium consisting of 15 subjects each with schizophrenia, bipolar disorder, major depression, and unaffected controls. All groups are matched for age, race, sex, and postmortem interval (Table 1) (Torrey et al., 2000). Slides were brought to room temperature, fixed in $4 \%$ formaldehyde $/ 1 \times$ PBS, acetylated in $0.25 \%$ acetic anhydride $/ 0.1 \mathrm{~m}$ triethanolamine- $\mathrm{HCl}, \mathrm{pH} 8.0$, delipidated with chloroform, and dehydrated in a series of graded ethanol solutions. ${ }^{35}$ S-labeled riboprobes, 5 $\mathrm{ng} / \mathrm{ml}$, were heat denatured before being added to the hybridization mixture (50\% formamide, $0.6 \mathrm{~mm} \mathrm{NaCl}, 10 \mathrm{~mm}$ Tris- $\mathrm{HCl}, \mathrm{pH} 7.5,0.02 \%$ Ficoll, $0.02 \%$ bovine serum albumin, $0.02 \%$ polyvinylpropyline, $1 \mathrm{~mm}$ EDTA, $0.01 \%$ salmon sperm DNA, $0.05 \%$ total yeast RNA, $0.005 \%$ yeast tRNA, $10 \%$ dextran sulfate, $0.1 \%$ sodium thiosulfate, $0.1 \mathrm{~m}$ dithiothreitol, and $0.1 \%$ SDS) and pipetted onto each section. Slides were then coverslipped and incubated overnight in $55^{\circ} \mathrm{C}$ humidified chambers. The coverslips were removed the next day, and the sections were subjected to posthybridization RNAase digestion. After washing the slides for $1 \mathrm{~h}$ each in different SSC solutions $\left(2 \times \mathrm{SSC}\right.$ at $50^{\circ} \mathrm{C}, 0.2 \times \mathrm{SSC}$ at $55^{\circ} \mathrm{C}$, and $0.2 \times$ SSC at $60^{\circ} \mathrm{C}$ ), the sections were dehydrated and exposed to BioMax film (Eastman Kodak) with ${ }^{14} \mathrm{C}$ standards (Weickert et al., 2005) for 8-11 d. For each subject, there were two antisense slides and one sense slide.

Image analysis. Densitometric image analysis was performed blind to diagnosis. Hippocampal subregions were defined by applying the anatomical paradigm of Lorento de Nó (Lorente de Nó, 1934; Kesner, 2007). The DLPFC was delineated by applying the anatomical paradigm of Rajkowska and Goldman-Rakic (1995a,b). The autoradiographic film images were digitized and calibrated to a ${ }^{14} \mathrm{C}$-standard curve (American Radiolabeled Chemicals) using the Rodbard function on NIH ImageJ (Weickert et al., 2005). The levels of VGF were calculated for regional quantification in microcuries. After decoding, log of the expression levels were analyzed with a linear mixed-effects model, using diagnosis as a fixed effect and film and subject as random effects. Time in storage was used as a covariate. Estimates were found using the lme4 package in the $\mathrm{R}$ statistical environment (R Development Core Team, 2009), with nominal highest posterior density intervals determined by Markov Chain Monte Carlo. $p$ values were found by repeatedly permuting the diagnosis labels and comparing the distribution of test statistics with those of the original data. Multiple comparisons were accounted for by, depending on the context, comparing the maximum test statistic across multiple diagnoses, multiple regions, or both multiple diagnoses and regions. Specifically, for the hippocampal subregions, these $p$ values were calculated by repeatedly permuting diagnosis labels and comparing the observed test statistic against the most extreme test statistics of each permutation across all diagnostic comparisons with controls (for the result on the entire pyramidal cell layer of the CA regions) and simultaneously (for the region specific results) over the four CA regions. Thus, the $p$ values include adjustment for multiple diagnoses and, for the CA1b and $\mathrm{CA} 2$ results, multiple regions. Time in storage was associated with diagnosis, so it was considered a covariate as a conservative measure. All comparisons were made between the controls and the bipolar disorder, major depression, or schizophrenia patients; no comparisons were made among the disease groups. The hippocampus and DLPFC were considered separately. One major depression and two schizophrenia samples were excluded from the analysis because of multiple outliers in those samples.

Silver grain analysis. The slides were dipped in emulsion (NTB-2 Emulsion; Eastman Kodak), dried, stored in light-tight containers, developed after 2 months in Kodak D19 Developer, and counterstained with cresyl violet. The silver grains were quantitated with BioQuant software. The percentage positive neurons and the average grains per cell were calculated for each region of each case. Pyramidal neurons were defined as having cell bodies $>25 \mu \mathrm{m}$ in diameter and by having a light Nissl-stained cell body with a darker staining nucleus present in the cross-section. Fifty CA pyramidal cells or 50 BA9 neurons were counted per subject. The number of grains per cell was counted within a standardized circular sample of $5 \mu \mathrm{m}$. A background measurement was taken by counting the grains in the standardized circular sample not overlying cells. Neurons containing grains per cell that were at least fivefold above background levels were considered positive (Weickert et al., 2005).

Mice. $V G F^{+/-}$mice that were generated, backcrossed, and maintained on a C57BL/6 background by Regeneron were obtained from Dr. Steve Salton (Mt. Sinai School of Medicine, New York, NY). Littermates from the colony were used as wild-type controls for the $V G F^{+/-}$mice. All other mice were wild-type C57BL/6 purchased from Hilltop Laboratories. All studies used male mice 3-4 months old.

Peptide treatment in vivo. Adult (3-4 month) male mice ( $\sim 30 \mathrm{~g})$ were anesthetized by intraperitoneal injection of 2,2,2-tribromoethanol in amyl alcohol (Avertin; Sigma) (1:80, $0.2 \mathrm{ml} / 10 \mathrm{~g}$ mouse). For chronic VGF treatment for novelty-induced hypophagia, mice were then implanted with a cannula in the lateral ventricle (Alzet Brain Infusion kit 3; DURECT Corporation). Coordinates were as follows: anteroposterior, $-0.1 \mathrm{~mm}$ with respect to bregma; lateral, $\pm 1.0 \mathrm{~mm}$; ventral, $-3.0 \mathrm{~mm}$ with respect to the surface of the skull (Bartolomucci et al., 2007). Cannulae were secured with Loctite glue. A $28 \mathrm{~d}$ osmotic minipump (Alzet 2004, $0.25 \mu \mathrm{l} / \mathrm{h}$ ) was loaded with saline or VGF (TLQP-62 C-terminal 
amidated peptide; Biopeptide) to deliver $15 \mu \mathrm{g} / \mathrm{d}$ intracerebroventricularly (Siuciak et al., 1997; Woodside et al., 2002; Bartolomucci et al., 2007; Ullal et al., 2007), connected to the cannula and implanted subcutaneously. A number of neuropeptides and neurotrophins have been shown to be stable after 14-24 d in the osmotic minipump (Shibayama et al., 1998; Larsen et al., 2000; Sahu, 2002; Hagg et al., 2005; Royo et al., 2006). To verify the correct placement of the cannulae after intracerebroventricular delivery of VGF, the mice were killed after behavioral studies, and cryostat sections through the cortex were cut to visualize the track of the cannula into the lateral ventricle. Only animals with the correct cannula placement were used for analysis. For acute VGF treatment for the hyperlocomotion assay, VGF was delivered to the hippocampus stereotaxically through a 30 gauge needle attached to a Hamilton syringe: anteroposterior, $-1.9 \mathrm{~mm}$ with respect to bregma; lateral, $\pm 1.5 \mathrm{~mm}$; ventral, $-1.5 \mathrm{~mm}$ with respect to the surface of the skull (Thakker-Varia et al., 2007). Mice received bilateral infusions of $0.2,1$, or $5 \mu \mathrm{g}$ of $1 \mu \mathrm{g} / \mu \mathrm{l}$ VGF delivered manually over $1 \mathrm{~min}$. The needle was left in place for $1 \mathrm{~min}$ after delivery to allow for diffusion of the neuropeptides.

Novelty-induced hypophagia. Training consisted of daily sessions for $11 \mathrm{~d}$ in which adult male mice were trained to drink a highly palatable food, diluted sweetened condensed milk (1:3 milk to water) from water bottles. Mice were acclimated to the testing room for $1 \mathrm{~h}$ before each training and home testing. Milk was placed in the cage for $15 \mathrm{~min} / \mathrm{d}$ during the training and testing period. Mice that never drank during the 15 min of daily training were eliminated from the experiment. After the training period, VGF (15 $\mu \mathrm{g} / \mathrm{d}$; Biopeptide) or saline was delivered by intracerebroventricular infusion using an osmotic minipump for $21 \mathrm{~d}$. Alternatively, in a separate set of mice, $\mathrm{LiCl}(100 \mathrm{mg} / \mathrm{kg}$; Sigma) or saline was given intraperitoneally two times per day for $21 \mathrm{~d}$. For positive controls, desipramine (DMI) (12.5 mg/kg; Sigma) was given intraperitoneally two times per day for $21 \mathrm{~d}$ to a separate set of mice. Testing in the home, novel, and home environment occurred on the last $3 \mathrm{~d}$ of the $21 \mathrm{~d}$ injection period $1 \mathrm{~h}$ after intraperitoneal injection. The time of training and testing for novelty-induced hypophagia was between 9:00 A.M. to 12:00 P.M. Latency to consume the milk solution was measured and recorded. For testing in the novel environment, mice were placed in an empty standard cage with no bedding but a white paper underneath and bright lighting overhead (2200 lux) to increase aversiveness. The cage was also sprayed with a cleaner (Pine Sol), and the experiment was performed in a novel testing room with no acclimation period. A failure to consume any milk was recorded as 15 min latency (Gur et al., 2007).

Locomotion open-field test. The open-field apparatus consisted of a $(40 \times 40 \times 49 \mathrm{~cm})$ clear Plexiglas arena with a white floor marked with tape dividing it into 12 equal quadrants. Stereotaxic surgery was used to infuse the hippocampi of male mice (3-4 months) with $1 \mu$ l of VGF $(0.2$, 1 , or $5 \mu \mathrm{g} / \mu \mathrm{l}$ ) or saline as described above $24 \mathrm{~h}$ before testing. VGF doses were based on previous studies (Hunsberger et al., 2007). Mice treated with $\mathrm{LiCl}$ were injected intraperitoneally ( $100 \mathrm{mg} / \mathrm{kg}$; Sigma) $1 \mathrm{~h}$ before testing. Locomotor activity of the mice in the open-field test was measured by counting the number of times mice crossed the tape from one square into an adjacent square within open-field arena in $5 \mathrm{~min}$ bins. Mice were subjected to a 15 min pretest to establish a baseline and eliminate novelty bias. The mice were then injected intraperitoneally with either saline or D-amphetamine ( $2 \mathrm{mg} / \mathrm{kg}$; Sigma) and replaced into the open field for a $40 \mathrm{~min}$ testing period. The open-field apparatus was wiped between trials with $70 \%$ ethanol solution (Gould et al., 2007). The level of illumination was 814 lux, and the experiments were performed between 12:00 P.M. and 5:00 P.M.

Hippocampal neuronal cultures. Embryonic day 16 mouse fetuses were removed from $\mathrm{CO}_{2}$-killed mice (Hilltop Laboratories) by cesarean section in accordance with institutional guidelines for care and use of animals and transferred to sterile PBS-containing Petri dishes. The hippocampus was dissected out from surrounding brain tissue, and the meninges were completely removed. Pooled tissue from each litter was mechanically dissociated in nutrient medium containing $7.5 \%$ fetal bovine serum and plated on poly-D-lysine-coated dishes at 350,000 cells per dish. Cultures were grown for $10 \mathrm{~d}$ in serum-free medium (ThakkerVaria et al., 2001), followed by treatment with VGF ( $3 \mu \mathrm{M}$; Biopeptide), LiCl (2 mm; Sigma) (Liang et al., 2008), or PBS for $48 \mathrm{~h}$. The dose of VGF was selected based on our previous in vitro studies (Thakker-Varia et al., 2007).

SDS-PAGE and Western blot analysis. Hippocampal neurons treated as above or hippocampi from mice exposed to either chronic (21 d) VGF (see above, Peptide treatment in vivo) or $\mathrm{LiCl}(100 \mathrm{mg} / \mathrm{kg}$, i.p., two times daily) were solubilized with lysis buffer (20 mu Tris, $0.5 \%$ Triton X-100, $0.5 \%$ SDS, 1 mм PMSF, 0.5 mm orthovanadate, protease inhibitor tablet, and phosphatase inhibitor cocktail, $\mathrm{pH} 8$ ). The protein content was determined using the BCA Protein Assay Reagent kit (Pierce). Equal amounts of protein were denatured in buffer with NuPAGE Sample Reducing Agent (Invitrogen) at $70^{\circ} \mathrm{C}$ for $10 \mathrm{~min}$, followed by separation on a $4-12 \%$ gradient Bis-Tris NuPAGE gel (Invitrogen). The proteins were transferred onto polyvinylidene difluoride-filter Immobilon-P transfer membranes (Millipore Corporation). Subsequently, the membranes were blocked with a solution of $5 \%$ milk plus $5 \%$ normal horse serum for $1 \mathrm{~h}$. The membranes were then subjected to incubation overnight at $4^{\circ} \mathrm{C}$ with antibodies against phospho-glycogen synthase kinase $3 \alpha(\operatorname{GSK} 3 \alpha)$ (Ser21), GSK3 $\alpha$, phospho-GSK3 $\beta$ (Ser9), GSK3 $\beta$, phospho-p44/42 mitogen-activated protein kinase (MAPK) (Thr202/ Tyr204), p44/42 MAPK, phospho-Akt (Ser473), Akt, and $\beta$-catenin. All antibodies were from Cell Signaling Technology and used at 1:1000 dilutions, except $\beta$-catenin, which was used at 1:4000 dilution. Actin was used for normalization at 1:500 (Santa Cruz Biotechnology). Membranes were washed, followed by $1 \mathrm{~h}$ incubation with donkey anti-rabbit or anti-mouse horseradish peroxidase-conjugated IgG (1: 3000; GE Healthcare) at room temperature. Proteins were detected using enhanced chemiluminescence (PerkinElmer Life and Analytical Sciences). Levels of the immunopositive bands were quantified densitometrically using Quantity One version 4.2.1 software (Bio-Rad) (Thakker-Varia et al., 2001).

Statistical analyses. Statistical methods for analysis of in situ radioactive films is described in detail above (see Image analysis). Statview software was used for analysis of all other data. Silver grain counts, noveltyinduced hypophagia with VGF, and Western blots for VGF treatments were analyzed using two-tailed $t$ test. Novelty-induced hypophagia with $\mathrm{LiCl}$ or DMI in WT and $V G F^{+/-}$, locomotion open-field test, and Western blots on chronic $\mathrm{LiCl}$ in vivo were analyzed using one-way ANOVA, followed by Fisher's protected least significant difference post hoc test as well as repeated-measures ANOVA accounting for multiple factors to determine interactions between factors and effects of over a time course when possible. Descriptive statistics were displayed as expressed mean \pm SEM, with significance at $p<0.05$.

\section{Results \\ $V G F$ mRNA is reduced in the hippocampus and prefrontal cortex of human bipolar disorder}

To elucidate the role of $V G F$ in psychiatric disorders, we examined VGF expression in postmortem tissue sections from the mid-hippocampus as well as the DLPFC from the Stanley Foundation Neuropathology Consortium consisting of coded samples from nonpsychiatric controls and patients with depression, bipolar disorder, and schizophrenia (Table 1). In hippocampal sections, ${ }^{35}$ S-labeled antisense probe gave a strong signal in the subgranular zone and granule cell layers of the dentate gyrus and the pyramidal layer of the CA regions, particularly CA2, as well as in the layers II-IV and VI of the inferior temporal lobe neocortex. The sense strand probe showed negligible hybridization, indicating the specificity of the probe (Fig. $1 A$ ). Quantitative analysis of the film-based autoradiograms from the in situ preparations using a linear mixed-effects model showed that VGF mRNA expression was significantly decreased in the entire pyramidal cell layer of the CA regions in the bipolar disorder samples relative to nonpsychiatric controls ( $p=0.024, n=15)$. Point estimates suggested downregulation of VGF mRNA in the CA regions for major depression and schizophrenia relative to nonpsychiatric controls, although these were not significant. When the data was analyzed by subregion within the hippocampus, CA1b showed 


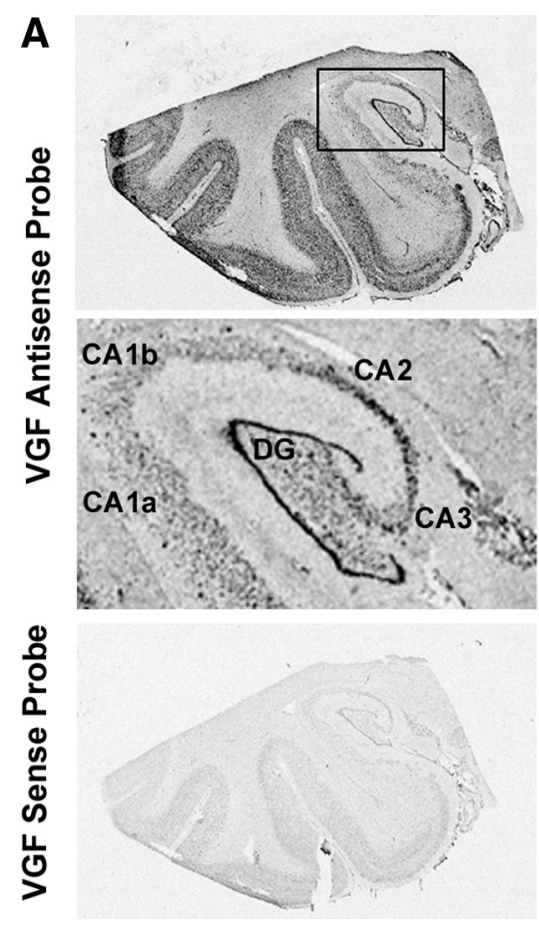

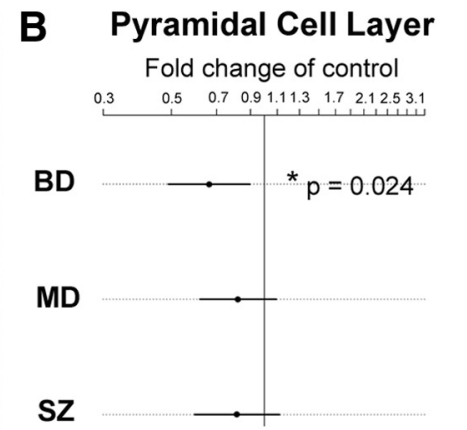

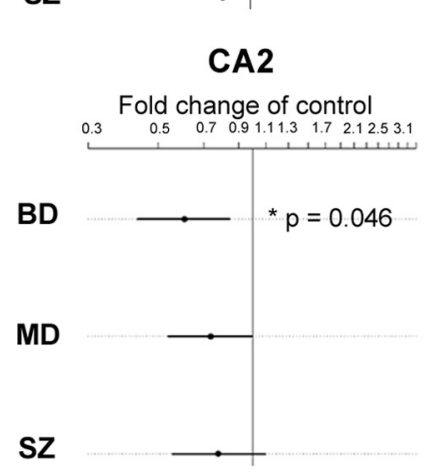

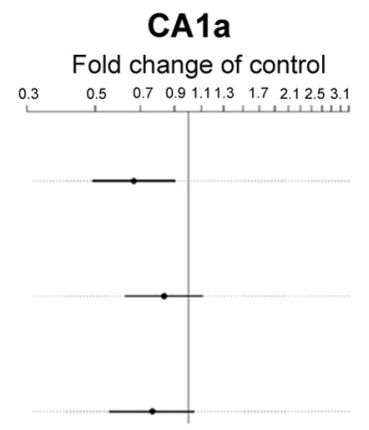

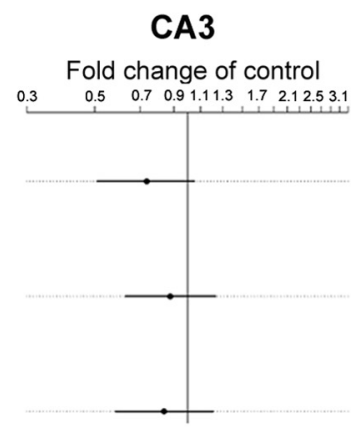

CA1b

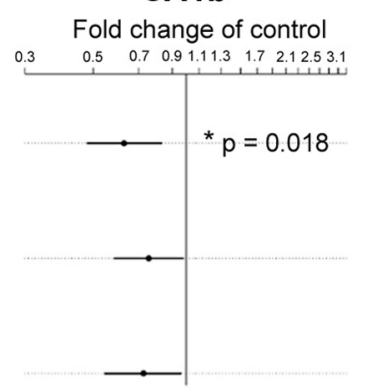

Dentate Gyrus

Fold change of control

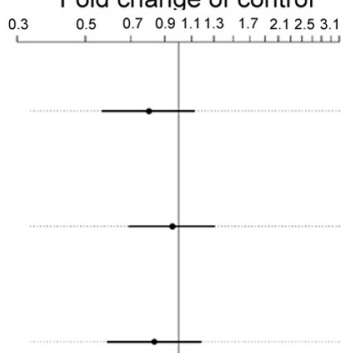

Figure 1. VGFmRNA expression is reduced in bipolar disorder patients in the CA region of the hippocampus. $A$, Representative autoradiographic film images of hybridization of $V G F$ antisense and sense probes in postmortem hippocampal sections. Boxed area in the antisense image is enlarged. ${ }^{35} \mathrm{~S}$-labeled antisense probe gives a strong signal in the subgranular zone and granule cell layer of the dentate gyrus and the pyramidal layer of the CA regions (CA1-CA3) as well as in the layers II-IV and VI of the inferior temporal lobe neocortex. The sense control probes give very low background hybridization. $\boldsymbol{B}$, Expression of VGF mRNA in the hippocampus of bipolar disorder (BD) ( $n=15)$, major depression (MD) $(n=14)$, and schizophrenia (SZ) ( $n=13)$ samples are expressed as fold change of nonpsychiatric controls (represented by vertical line) $(n=15)$. Log of the expression levels were analyzed with a linear mixed-effects model, using diagnosis as a fixed effect and film and subject as random effects. Time in storage was used as a covariate. Estimates were found using the Ime4 package in the $R$ statistical environment, with nominal highest posterior density intervals determined by Markov Chain Monte Carlo. $p$ values were found by repeatedly permuting diagnosis labels and comparing the observed test statistic against the most extreme test statistics of each permutation across all diagnostic comparisons with controls (for the result on the entire pyramidal cell layer of the (A regions) and simultaneously (for the region-specific results) over the four CA regions. A trend toward decreased expression in the CA regions of the hippocampus was detected in all diagnoses relative to nonpsychiatric controls with statistically significantly reduced expression in bipolar disorder ( $\left.{ }^{*} p=0.024\right)$. When the data were analyzed by subregion within the hippocampus, CA1b showed significantly reduced expression for bipolar disorder compared with nonpsychiatric controls ( $\left.{ }^{*} p=0.018\right)$, as did CA2 ( $\left.{ }^{*} p=0.046\right)$. Analysis of dentate gyrus includes the subgranular zone, the granule cell layer, and the hilar regions.

significantly reduced expression for bipolar disorder compared with control samples ( $p=0.018, n=15)$, as did CA2 ( $p=0.046$, $n=15$ ) for bipolar disorder (Fig. $1 B$ ). CAla was near significance $(p=0.0834)$. These $p$ values were calculated by repeatedly permuting diagnosis labels and comparing the observed test statistic against the most extreme test statistics of each permutation across all diagnostic comparisons with controls (for the result on the entire pyramidal cell layer of the CA regions) and simultaneously (for the region-specific results) over the four CA regions. Thus, the $p$ values include adjustment for multiple diagnoses and, for the CA1b and CA2 results, multiple regions. There was no significant correlation between VGF mRNA levels and age, $\mathrm{pH}$, postmortem interval (PMI), or gender. Time in storage was associated with diagnosis, so it was considered a covariate as a conservative measure. All comparisons were made between the controls and the bipolar disorder, major depression, or schizophrenia patients; no comparisons were made among the disease groups.

To assess whether the observed effect might simply be a proxy for lifetime use of fluphenazine or equivalent, we performed similar linear mixed-effects regressions of expression against lifetime use of fluphenazine (or equivalent, as determined by the Stanley Foundation) separately for both bipolar disorder and schizophrenia patients. No control or major depression patients reported fluphenazine use. There was no association of VGF mRNA expression with lifetime fluphenazine levels among either schizophrenia patients $(p=0.222)$ or bipolar disorder patients $(p=$
0.718) when analyzed over the CA and dentate regions. The smallest nominal $p$ value for an individual region was 0.078 in CA3 for schizophrenia patients. These results suggest that medication use did not account for the changes in VGF expression.

The density of silver grains over an individual neuron was used to determine the relative level of mRNA expression per cell. Cellular analysis revealed a reduction in the number of silver grains per CA pyramidal neuron in the bipolar disorder samples relative to nonpsychiatric controls $\left(t_{(26)}=2.54, p=0.0173\right)$. There was no change in the number of CA pyramidal cells expressing VGF mRNA in bipolar disorder samples $\left(t_{(26)}=0.613\right.$, $p=0.5449$ ) (Fig. 2). No obvious signal was seen overlying small darkly Nissl-stained nuclei, which are probably either glia or interneurons. Together, these data suggest that there is a downregulation of $V G F$ mRNA in each pyramidal cell but that the same numbers of cells express $V G F$ in control and bipolar disorder patients.

In the human DLPFC, we detected low-density VGF mRNA expression in layer V, moderate levels in layers I, II, and VI, and high density deep in layers III and IV. The sense control probe again showed negligible hybridization signal (Fig. 3A). BA9 and BA46 of the DLPFC were selected for quantitative analysis. Although for the sake of completeness the data were graphed for all three diagnoses relative to nonpsychiatric controls, the statistical analyses for BA9 and BA46 were based only on bipolar disorder versus nonpsychiatric controls. Significantly reduced VGF mRNA levels were found in the BA9 region of the DLPFC for 
A
Control

B

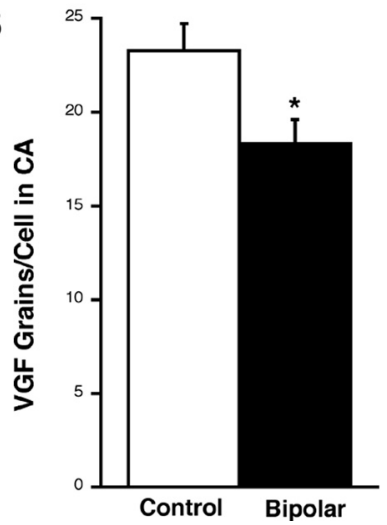

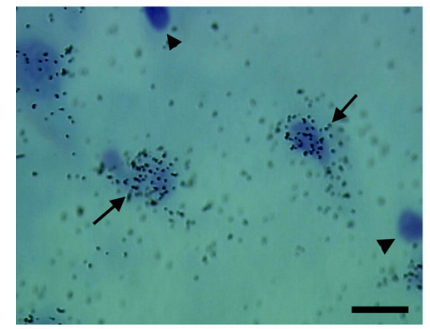
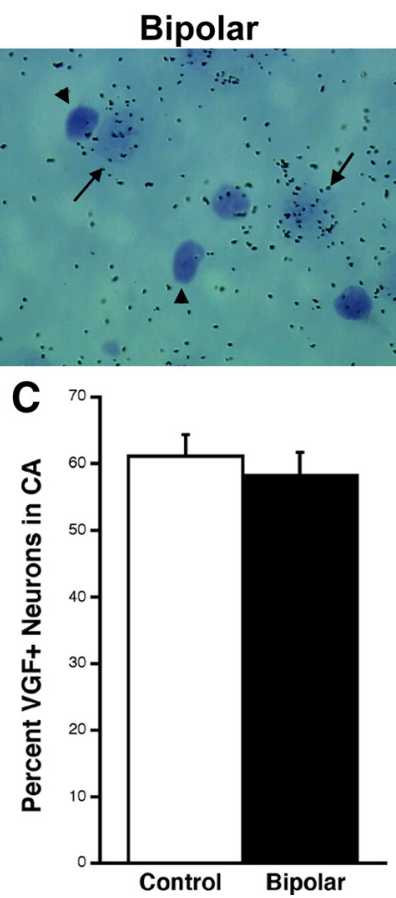

Figure 2. Bipolar samples have a reduction in the levels of VGF mRNA per (A pyramidal neuron but not in the number of cells expressing VGF. A, Bright-field photomicrograph (100X) demonstrating VGF mRNA hybridization signal in the CA region of the human hippocampus. Black arrows indicate pyramidal cells that are more strongly labeled in control patients than in bipolar disorder. Arrowheads indicate cells darkly stained with cresyl violet that do not express $V G F$ mRNA. Scale bar, $50 \mu \mathrm{m}$. $\boldsymbol{B}$, Bar graph of the average \pm SEM number of silver grains per VGF mRNA-positive CA pyramidal neuron in control and bipolar patients $\left({ }^{*} t_{(26)}=2.54, p=\right.$ 0.0173). C, Bar graph of the mean \pm SEM percentage of neurons positive for VGF mRNA in CA pyramidal cells of control and bipolar disorder patients. There is no significant change detected $\left(t_{(26)}=0.613, p=0.5449\right)$. Fifty cells were counted per sample $(n=14)$.

bipolar disorder $(p=0.046$ adjusted for comparisons in the two regions, $n=15$ ). No change in VGF mRNA expression was observed in BA46 for any of the three diagnoses (Fig. 3B). Cellular expression analysis was performed for cortical layer VI within BA9. Similar to the CA region of the hippocampus, there was a reduction in the number of silver grains per neuron in the bipolar disorder samples relative to nonpsychiatric controls $\left(t_{(28)}=\right.$ 2.216, $p=0.0350$ ) but no change in the number of BA9 cells expressing VGF mRNA in bipolar disorder samples $\left(t_{(28)}=\right.$ $0.198, p=0.8445$ ) (Fig. 4). Together, these results demonstrate that VGF mRNA levels are reduced in each cell in the CA region of the hippocampus and BA9 in the DLPFC of bipolar disorder patients.

\section{VGF contributes to the effects of $\mathrm{LiCl}$ in a behavioral} procedure that responds to chronic antidepressant treatment To elaborate the role of VGF in bipolar disorder, we used a behavioral procedure, novelty-induced hypophagia, which is only sensitive to the effects of chronic, but not acute or subchronic, antidepressant treatment (Dulawa et al., 2004; Cryan and Holmes, 2005; Dulawa and Hen, 2005). In brief, mice were trained for $11 \mathrm{~d}$ to drink sweetened condensed milk, and then compounds of interest were administered for $21 \mathrm{~d}$. The mice were then tested for latency to drink the sweetened condensed milk in the home cage as well as a novel environment and then again in the home cage. Home cage consumption latency is a control for feeding behavior. A reduced latency to drink in the novel environment is indicative of the effectiveness of a compound as an antidepressant-like agent. The effect of acute treatment with VGF in novelty-induced hypophagia has already been examined (Hunsberger et al., 2007).

To test whether chronic VGF has antidepressant-like effects in novelty-induced hypophagia, VGF $(15 \mu \mathrm{g} / \mathrm{d})$ or saline was infused continuously for $21 \mathrm{~d}$ using an osmotic minipump into the lateral ventricle. The dose of VGF was selected based on studies infusing VGF peptides as well as other neuropeptides and neurotrophins (Siuciak et al., 1997; Woodside et al., 2002; Bartolomucci et al., 2007; Ullal et al., 2007). Importantly, there was no difference in the weight change during the $21 \mathrm{~d}$ period between saline- and VGF-treated mice $(-3.1 \pm 1.2 \mathrm{~g}$ of saline, $-4.7 \pm 0.9 \mathrm{~g}$ of VGF, $\left.t_{(9)}=1.026, p=0.3316\right)$, suggesting that intracerebroventricular VGF infusion had no effect on food consumption. Furthermore, VGF had no effect on latency to drink the milk in the home cage on either day of testing, consistent with the lack of effect on baseline behavior $\left(t_{(9)}=-0.358, p=0.7289 ; t_{(9)}=0.558, p=\right.$ $0.5903)$. Interestingly, VGF reduced the latency to drink the milk in the novel environment $\left(t_{(9)}=2.264, p=0.0498\right)$ (Fig. $\left.5 A\right)$. A number of other neuropeptides and neurotrophins have been shown to be stable after $14-24 \mathrm{~d}$ in the osmotic minipump (Shibayama et al., 1998; Larsen et al., 2000; Sahu, 2002; Hagg et al., 2005; Royo et al., 2006). However, because the extent of degradation of peptides depends on several factors, including amino acid sequence and conformation, it is possible that there was some degradation of the VGF in the osmotic minipump. Despite that possibility, we did see a positive effect of chronic VGF in novelty-induced hypophagia. Together, these data suggest that VGF has effects in a procedure that requires chronic antidepressant treatment.

$\mathrm{LiCl}$ is the prototypical mood stabilizer for bipolar disorder (Malhi et al., 2009), but its activity in novelty-induced hypophagia had not been examined. Therefore, to test the efficacy of $\mathrm{LiCl}$ in novelty-induced hypophagia, a separate set of WT mice was trained to drink milk, and $\mathrm{LiCl}(100 \mathrm{mg} / \mathrm{kg}$, two times daily) or saline was injected intraperitoneally for $21 \mathrm{~d}$. Like VGF, $\mathrm{LiCl}$ reduced the latency to drink the milk in the novel environment compared with saline treatment $\left(F_{(2,19)}=3.376\right.$, Fisher's $p=$ $0.019)$ but had no effect on latency to drink in the home cage on either day of testing $\left(F_{(2,19)}=0.029\right.$, Fisher's $p=0.9191 ; F_{(2,19)}=$ 0.137 , Fisher's $p=0.9704$ ) (Fig. $5 B$ ). These findings demonstrate that $\mathrm{LiCl}$ is also an effective compound in an assay that responds to chronic antidepressant treatment.

To address whether VGF contributes to the effects of $\mathrm{LiCl}$, we performed novelty-induced hypophagia in mice with genetically reduced levels of $V G F$. In our hands, there were very low numbers of $V G F^{-1-}$ mice born, and the viability was also very low. Therefore, these experiments were performed on $V G F^{+/-}$mice, which display no differences in normal anxiety levels in elevated-plusmaze and open-field tests but do exhibit behavioral deficits in response to exercise (Hunsberger et al., 2007) and have reduced response in learning and memory tasks (Bozdagi et al., 2008). Those studies suggest that the reduced levels of VGF in heterozygous mice are sufficient to cause a deficit in depression and memory paradigms and therefore are useful genetic models. In contrast to $\mathrm{LiCl}$ in WT mice, $\mathrm{LiCl}(100 \mathrm{mg} / \mathrm{kg}$, two times daily for $21 \mathrm{~d})$ in $V G F^{+/-}$mice did not significantly reduce the latency to drink in the novel environment relative to saline $\left(F_{(2,19)}=3.376\right.$, Fisher's $p=0.2791)$, suggesting that VGF may contribute to the effects of LiCl in novelty-induced hypophagia (Fig. $5 B$ ). As in WT mice, $\mathrm{LiCl}$ in the $V G F^{+/-}$mice had no effect on the latency to drink in the home environments $\left(F_{(2,19)}=0.029\right.$, Fisher's $p=$ $0.8137 ; F_{(2,19)}=0.137$, Fisher's $\left.p=0.6873\right)$. There was a signifi- 
A

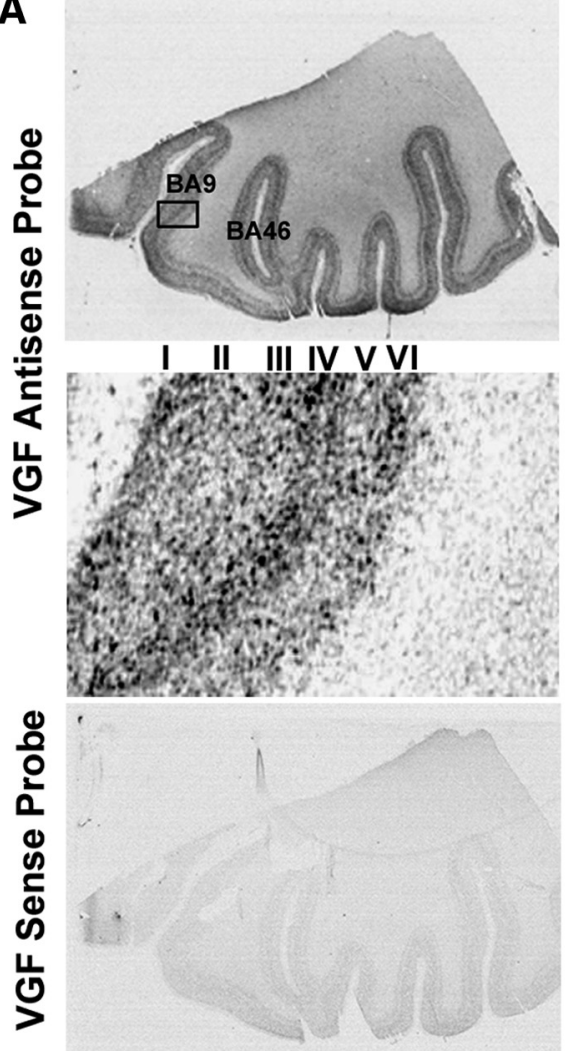

B

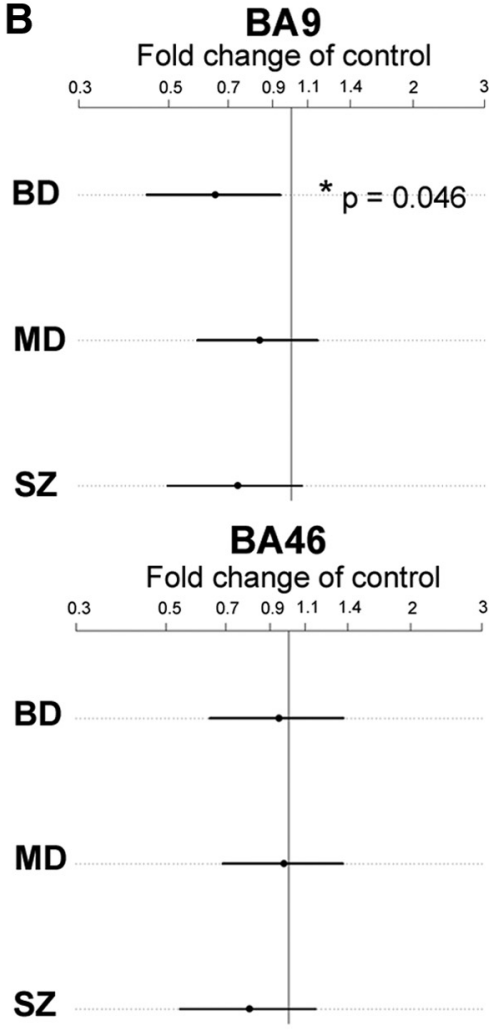

Figure 3. VGF mRNA expression is reduced in bipolar disorder patient in BA9 of the prefrontal cortex. $A$, Representative autoradiographic film images of hybridization of VGF antisense and sense probes in the prefrontal cortex. Boxed area in the antisense image is enlarged. There is light expression in layer V, moderate levels in layers I, II, and VI, and high density expression deep in layers III and IV. BA9 and BA46 are indicated. The sense control probes give very low background hybridization. $\boldsymbol{B}$, Expression of VGF mRNA in the cortex of bipolar disorder (BD) ( $n=15)$, major depression (MD) ( $n=15)$, and schizophrenia (SZ) $(n=15)$ samples are expressed as fold change of nonpsychiatric controls (represented by vertical line) ( $n=15)$. Log of the expression levels were analyzed with a linear mixed-effects model, using diagnosis as a fixed effect and film and subject as random effects. Time in storage was used as a covariate. Estimates were found using the Ime4 package in the Rstatistical environment, with nominal highest posterior density intervals determined by Markov Chain Monte Carlo and $p$ values found by permutation tests comparing the maximum test statistic across both regions. The difference was significant in BA9 $\left({ }^{*}\right.$ nominal $\left.p=0.046\right)$.

cant interaction between cage condition and drug $\left(F_{(2,20)}=\right.$ $3.517, p=0.0392$ ). There was no significant difference in weight in the chronic LiCl-treated mice compared with saline (1.3 \pm $1.9 \mathrm{~g}$ of saline, $0.7 \pm 0.5 \mathrm{~g}$ of $\left.\mathrm{LiCl}, t_{(10)}=0.803, p=0.4405\right)$, suggesting that $\mathrm{LiCl}$ had no effect on general appetite and that the health of the LiCl-treated animals was good. Chronic LiCl had no obvious effect on general health as confirmed by necropsy after 3 weeks of $\mathrm{LiCl}$ by intraperitoneal injection in which only small regions of congestion was observed at the site of injection in both saline- and LiCl-treated mice.

To examine whether VGF contributes to the effects of traditional antidepressants, we administered the tricyclic DMI (12.5 $\mathrm{mg} / \mathrm{kg}$, i.p.) (Gur et al., 2007) for $21 \mathrm{~d}$ to $V G F^{+/-}$and WT mice that had been trained to drink the sweetened condensed milk. Our results confirm that DMI injections administered intraperitoneally reduce the latency to drink in the novel environment relative to saline controls $\left(F_{(2,13)}=3.765\right.$, Fisher's $\left.p=0.0169\right)$ but had no effect on latency in the home cage on either day of testing $\left(F_{(2,13)}=0.875\right.$, Fisher's $p=0.2566 ; F_{(2,13)}=0.415$, Fisher's $p=0.8236)$. The response to both VGF and $\mathrm{LiCl}$ was comparable with that of DMI. In contrast to DMI in WT mice, DMI in $V G F^{+/-}$mice did not significantly reduce the latency to drink in the novel environment relative to saline $\left(F_{(2,13)}=3.765\right.$, Fisher's $p=$
0.2187) (Fig. 5C). There was a significant interaction between cage condition and drug $\left(F_{(2,14)}=4.845, p=0.0156\right)$. Therefore, there may be a contribution of VGF to the mechanism of DMI as well as $\mathrm{LiCl}$ in novelty-induced hypophagia.

\section{VGF mimics the effects of $\mathrm{LiCl}$ and is required in a mouse system that phenocopies manic-like behavior} We further explored the role of VGF in bipolar disorder by testing its effect in amphetamine-induced hyperactivity, which has been used to phenocopy manic-like behavior and test novel lithium-mimetic compounds (Poncelet et al., 1987; Takigawa et al., 1994; Beaulieu et al., 2004; Frey et al., 2006; Gould et al., 2007; Shaldubina et al., 2007; Du et al., 2008; Shaltiel et al., 2008). Mice were acclimated to the open-field apparatus for $15 \mathrm{~min}$ and then injected with either amphetamine $(2 \mathrm{mg} /$ $\mathrm{kg}$ ) or saline intraperitoneally, followed immediately by a $40 \mathrm{~min}$ open-field test. Within 10 min after amphetamine injection, there is enhanced locomotion as indicated by an increase in the number of crossings in the open-field apparatus. We explored the effect of pretreatment with a single dose of VGF stereotaxically into the hippocampus in this procedure. The doses of VGF were selected based on its effectiveness in previous in vivo assays (Hunsberger et al., 2007); VGF was tested at $0.2,1$, and $5 \mu \mathrm{g}$. None of the VGF doses tested had an effect relative to saline injection on the number of crossings in the absence of amphetamine ( $-5 \mathrm{~min}$ pretest, $F_{5,31}=1.850$, Fisher's $p=0.9022,0.4410$, and 0.1264 for $0.2,1$, and $5 \mu \mathrm{g}$, respectively), consistent with our previous findings that VGF does not affect baseline locomotion (Thakker-Varia et al., 2007). However, after amphetamine injection, 1 and $5 \mu \mathrm{g}$ VGF-treated mice displayed significantly reduced hyperlocomotion in response to amphetamine relative to mice preinfused with saline $(25 \mathrm{~min}$ after amphetamine, $F_{5,31}=36.088$, Fisher's $p=0.0004$ and 0.0001 for 1 and $5 \mu \mathrm{g}$, respectively) (Fig. $6 A$ ). There was a significant interaction between drug and session time $\left(F_{(10,19)}=2.580\right.$, $p=0.0059)$ and between dose and session time $\left(F_{(30,21)}=3.306\right.$, $p<0.0001)$. Thus, a dose-response effect is observed for the behavioral effects of VGF in vivo. These findings indicate that VGF has novel actions that attenuate manic-like properties, similar to those observed with $\mathrm{LiCl}$ treatment.

To determine whether $V G F$ is involved in the behavioral response to amphetamine, we administered amphetamine to $V G F^{+/-}$mice. $V G F^{+/-}$mice displayed no difference from WT mice in the open-field arena after saline injection (30 min after amphetamine, $F_{(3,21)}=16.058$, Fisher's $\left.p=0.9278\right)$, suggesting that endogenous VGF is not required for normal locomotor activity. However, $V G F^{+/-}$mice had increased hyperactivity relative to the WT mice after amphetamine injection (30 min after amphetamine, $F_{(3,21)}=16.058$, Fisher's $p=0.0444$ ) (Fig. $6 B$ ). There was a significant interaction between genotype and session 
time $\left(F_{(10,21)}=2.126, p=0.0238\right)$ and between drug and session time $\left(F_{(10,21)}=2.580, p=0.0059\right)$ and a trend toward an interaction between genotype, drug, and session time $\left(F_{(10,21)}=1.660\right.$, $p=0.0919)$. Because reduced levels of $V G F$ result in enhanced reaction, these data suggest that endogenous $V G F$ is necessary for tempering the response to amphetamine.

The requirement for $V G F$ in the actions of $\mathrm{LiCl}$ was examined using $V G F^{+/-}$mice treated with $\mathrm{LiCl}$. We confirmed previous studies demonstrating that pretreatment with lithium intraperitoneally $(100 \mathrm{mg} / \mathrm{kg}) 1 \mathrm{~h}$ before amphetamine injection in WT mice attenuates amphetamine-induced hyperactivity relative to WT mice pretreated with saline before injection with amphetamine $\left(30\right.$ min after amphetamine, $F_{(4,25)}=11.904$, Fisher's $p=$ 0.0035) (Fig. 6C) (Takigawa et al., 1994; Frey et al., 2006; Gould et al., 2007; O'Donnell and Gould, 2007). The response to amphetamine of $\mathrm{VGF}^{+/-}$mice pretreated with $\mathrm{LiCl}$ was indistinguishable from that of WT mice pretreated with saline, suggesting that $\mathrm{LiCl}$ has no effect in $V G F^{+/-}$mice (30 min after amphetamine, $F_{(4,25)}=11.904$, Fisher's $\left.p=0.9056\right)$. Confirming this finding, LiCl-pretreated WT mice were significantly different from LiClpretreated $V G F^{+/-}$mice $\left(30\right.$ min after amphetamine, $F_{(4,25)}=$ 11.904 , Fisher's $p=0.0026)$. There was a significant interaction between drug and session time $\left(F_{(8,19)}=3.066, p=0.0031\right)$ and for genotype and session time $\left(F_{(8,10)}=5.292, p<0.0001\right)$. Together, these data suggest that VGF is necessary for the effects of $\mathrm{LiCl}$ in curbing the effects of amphetamine in a mouse system that phenocopies manic-like behavior.

VGF activates the same signaling cascades as $\mathrm{LiCl}$ and is required for the activation of those pathways

Because the receptor for VGF has not yet been identified, little is known about the signaling pathways downstream of VGF. Because we have shown that VGF mimics many of the behavioral effects of $\mathrm{LiCl}$, we examined whether VGF activates any of the signaling cascades regulated by $\mathrm{LiCl}$. We have confirmed that $\mathrm{LiCl}$ (2 $\mathrm{mm}$ ) induces increasing trends in phosphorylation of p42 MAPK (Tyr204), Akt (Ser473), and GSK3 $\beta$ (Ser9) in hippocampal cultures (Fig. $7 A, B$ ) (Liang et al., 2008; Aubry et al., 2009): p42 MAPK (control, $2.05 \pm 0.57 \mathrm{OD} / \mathrm{mm}^{2}$ and $\mathrm{LiCl}$, $5.07 \pm 1.21 \mathrm{OD} / \mathrm{mm}^{2}$ normalized to $2.76 \pm 0.61$-fold of average control, $t_{(6)}=$ $-2.883, p=0.028$ ), Akt (control, $0.41 \pm$ $0.12 \mathrm{OD} / \mathrm{mm}^{2}$ and $\mathrm{LiCl}, 0.61 \pm 0.24 \mathrm{OD} /$ $\mathrm{mm}^{2}$ normalized to $1.33 \pm 0.21$-fold of average control, $t_{(6)}=-1.522, p=$ 0.179 ), and GSK $3 \beta$ (control, $0.90 \pm 0.22$ $\mathrm{OD} / \mathrm{mm}^{2}$ and $\mathrm{LiCl}, 2.07 \pm 0.55 \mathrm{OD} / \mathrm{mm}^{2}$ normalized to $2.50 \pm 0.83$-fold of average control, $\left.t_{(6)}=-1.874, p=0.120\right)$.

Treatment of hippocampal cultures for $48 \mathrm{~h}$ with $\operatorname{VGF}(3 \mu \mathrm{M})$, as we have used previously (Thakker-Varia et al., 2007), induced phosphorylation of p42 MAPK, Akt, and GSK3 $\beta$ to a similar degree as $\mathrm{LiCl}$ (Fig. $7 A, B$ ): p42 MAPK (control, $2.05 \pm 0.57 \mathrm{OD} / \mathrm{mm}^{2}$ and VGF, $4.44 \pm 1.41$ $\mathrm{OD} / \mathrm{mm}^{2}$ normalized to $2.14 \pm 0.30$-fold of average control, $t_{(6)}$ $=-3.776, p=0.009$ ), Akt (control, $0.41 \pm 0.12 \mathrm{OD} / \mathrm{mm}^{2}$ and VGF, $0.60 \pm 0.20 \mathrm{OD} / \mathrm{mm}^{2}$ normalized to $1.43 \pm 0.13$-fold of average control, $t_{(6)}=-3.327, p=0.016$ ), and GSK3 $\beta$ (control,
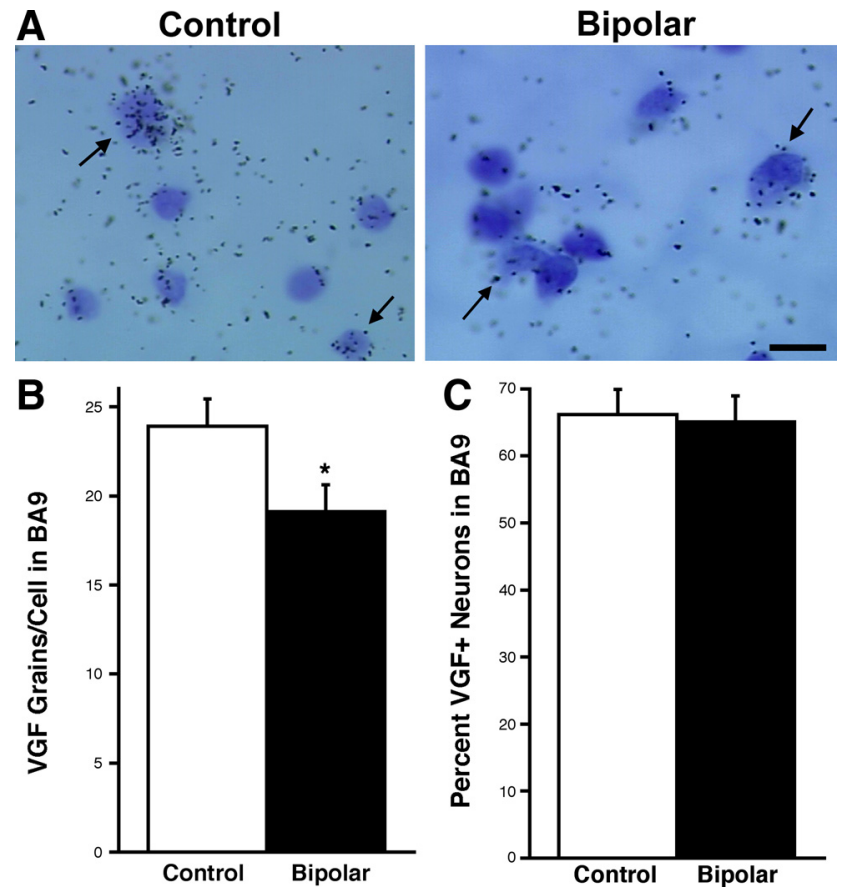

Figure 4. Silver grain analysis in BA9 reveals less VGF mRNA per cell but no change in the number of VGF-positive neurons. A, Bright-field photomicrograph $(100 \times)$ demonstrating VGF $m R N A$ hybridization signal in layer VI of BA9. Black arrows indicate the polymorphic layer cells that are more strongly labeled in control patients than in bipolar disorder patients. Scale bar, 25 $\mu \mathrm{m} . \boldsymbol{B}$, Bar graph of the average \pm SEM number of silver grains per VGFmRNA-positive layer VI neurons in control and bipolar patients $\left({ }^{*} t_{(28)}=2.216, p=0.0350\right)$. C, Bar graph of the mean \pm SEM percentage of neurons positive for VGF mRNA in layer VI cells of control and bipolar patients. There is no significant change detected $\left(t_{(28)}=0.198, p=0.8445\right)$. Fifty cells were counted per sample $(n=15)$.
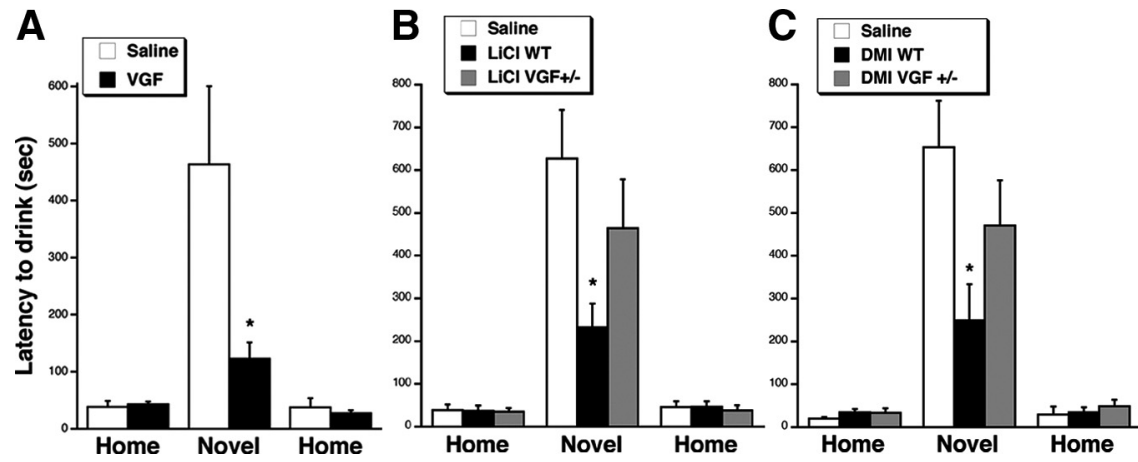

Figure 5. Chronic VGF, LiCl, and DMI reduce latency to drink in novelty-induced hypophagia in WT but not VGF ${ }^{+/-}$mice. Bars represent mean latencies for mice to consume sweetened condensed milk in the home, novel, and home environments on days 19 , 20 , and 21, respectively, during treatment with VGF or saline by intracerebroventricular infusion $(\boldsymbol{A})$. There was a decreased latency to consume in the VGF-treated mice relative to saline-treated WT animals in the novel environment $\left({ }^{*} t_{(9)}=2.264, p=0.0498\right)$. $\boldsymbol{B}, \mathrm{LiCl}$ or saline by intraperitoneal injection into WT and $V G F^{+/-}$mice. There was a decreased latency to consume in the $\mathrm{LiCl}$ treated mice relative to saline-treated WT mice in the novel environment $\left({ }^{*} F_{(2,19)}=3.376\right.$, Fisher's $\left.p=0.019\right)$, but the effect of $\mathrm{LiCl}$ versus saline was not apparent in $V G F^{+/-}$mice $\left(F_{(2,19)}=3.376\right.$, Fisher's $\left.p=0.2791\right)(n=6-9)$. C, DMI or saline by intraperitoneal injection into WT and $V G F^{+/-}$mice. There was a decreased latency to consume in the DMI-treated relative to saline-treated WT animals in the novel environment $\left({ }^{*} F_{(2,13)}=3.765\right.$, Fisher's $\left.p=0.0169\right)$, but the effect of DMI versus saline was not apparent in $V G F^{+/-}$mice $\left(F_{(2,13)}=3.765\right.$, Fisher's $\left.p=0.2187\right)(n=5,6)$. Error bars represent SEM.
$0.90 \pm 0.22 \mathrm{OD} / \mathrm{mm}^{2}$ and VGF, $1.66 \pm 0.44 \mathrm{OD} / \mathrm{mm}^{2}$ normalized to $2.32 \pm 0.54$-fold of average control, $t_{(6)}=-2.522, p=$ $0.045)$.

In our hands, phospho-GSK3 $\alpha$ (Ser21) and $\beta$-catenin levels were not significantly altered by either VGF or $\mathrm{LiCl}$ in hippocampal cultures (Fig. $7 A, B$ ): GSK $\alpha$ (control, $0.63 \pm 0.18 \mathrm{OD} / \mathrm{mm}^{2}$ 

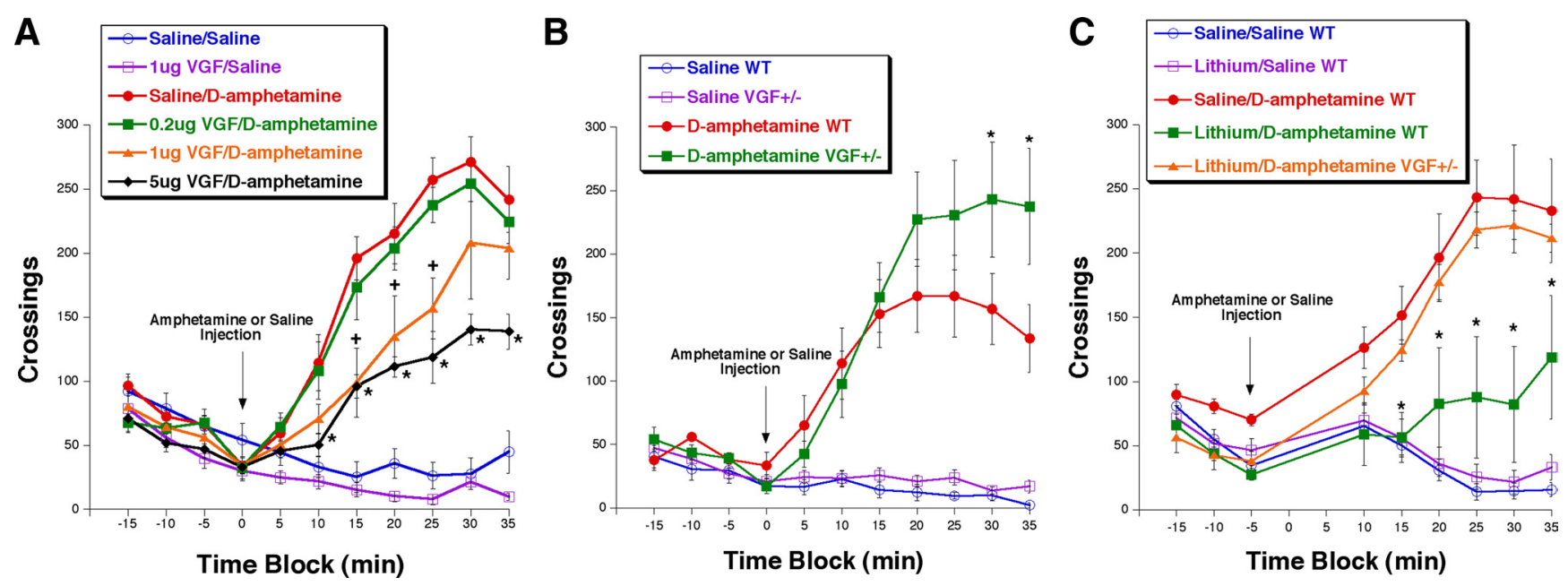

Figure 6. VGF infusion in the hippocampus reduces hyperactivity, and $V G F^{+/-}$mice have increased response to amphetamine and do not respond to LiCl. $A$, Average $\pm S E M$ number of total crossings in 5 min bins. Mice were infused intrahippocampally with either saline (circles) or VGF (other shapes). Twenty-four hours later, the mice were acclimated to the open-field apparatus for 15 min, followed by intraperitoneal injection (indicated by arrow) of either amphetamine (filled symbols) or saline (open symbols). Total crossings were monitored for an additional 40 min ( $n=5-7$ ). ${ }^{*} p<0.05, \mathrm{VGF} / \mathrm{D}$-amphetamine is significantly different from saline/D-amphetamine by ANOVA, Fisher's post hoc test. B, Average \pm SEM number of total crossings in 5 min bins. WT (circles) and VGF heterozygote $\left(\mathrm{VGF}^{+/-}\right)$(squares) mice were acclimated to the open-field apparatus for $15 \mathrm{~min}$, followed by intraperitoneal injection (indicated by arrow) of either amphetamine (filled symbols) or saline (open symbols). Total crossings were monitored for an additional $40 \mathrm{~min}(n=6,7) .{ }^{*} p<0.05$, D-amphetamine $V G F^{+/-}$is significantly different from saline/D-amphetamine WT by ANOVA, Fisher's post hoc test. C, VGF ${ }^{+/-}$mice do not respond to LiCl treatment. Average \pm SEM number of total crossings in 5 min bins. Mice were given either saline (circles) or LiCl (other shapes) intraperitoneally. One hour later, the mice were acclimated to the open-field apparatus for $15 \mathrm{~min}$, followed by intraperitoneal injection (indicated by arrow) of either amphetamine (filled symbols) or saline (open symbols). Total crossings were monitored for an additional $40 \mathrm{~min}(n=6){ }^{*} p<0.05$, LiCl/D-amphetamine VGF ${ }^{+/-}$is significantly different from LiCl/D-amphetamine WT by ANOVA, Fisher's post hoc test.
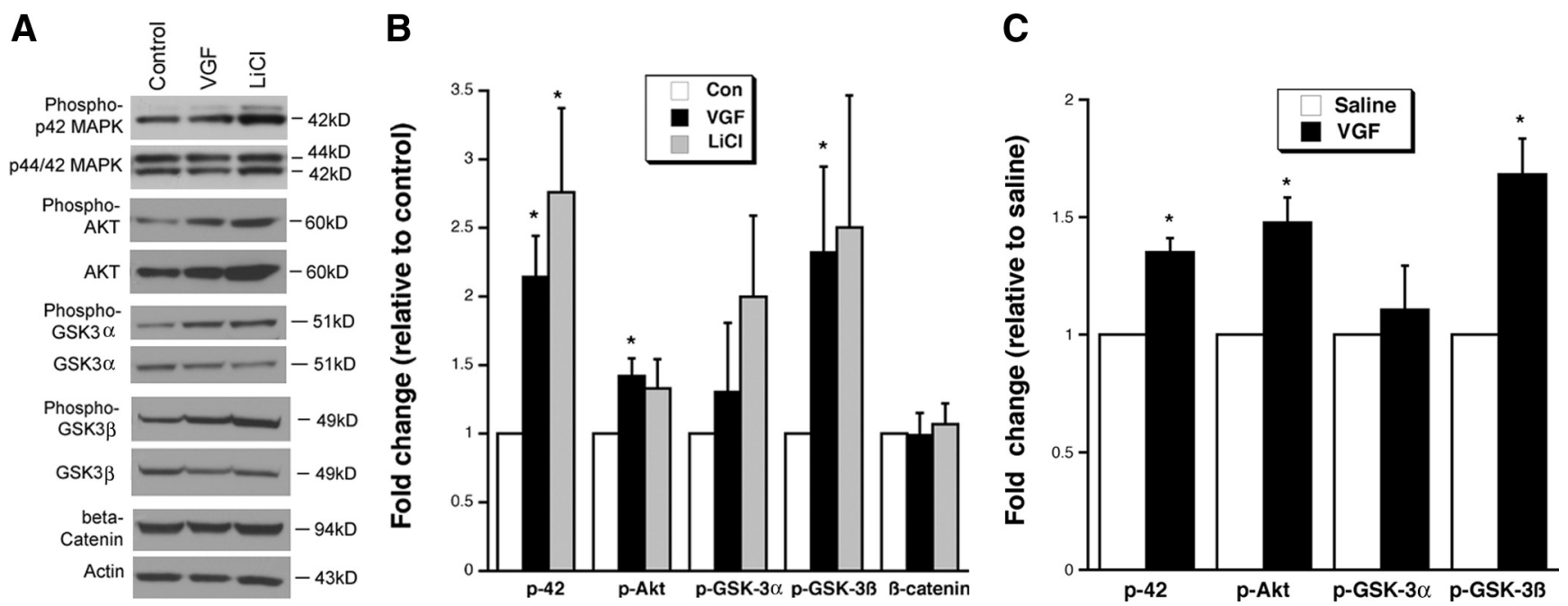

Figure 7. VGF activates the same signaling pathways as LiCl in vitro and in vivo. A, Representative Western blots demonstrating that $48 \mathrm{~h}$ VGF treatment induces increases in phosphorylation of p42 MAPK, Akt, and GSK3 $\beta$ in hippocampal neurons in culture. GSK3 $\alpha$ and $\beta$-catenin did not show as dramatic a change. LiCl is used as a positive control. $\boldsymbol{B}$, Bar graph represents the densitometric analyses of the phosphorylated form of each protein that is normalized to its nonphosphorylated species after VGF or LiCl in vitro. $\beta$-Catenin protein level changes are normalized to actin. All data are expressed as fold change relative to the average of untreated hippocampal neuron cultures (control). ${ }^{*} p<0.05$, samples are significantly different from control samples by two-tailed $t$ test $(n=$ 4). C, Bar graph represents the densitometric analyses of the phosphorylated form of each protein that is normalized to its nonphosphorylated species after chronic VGF intracerebroventricular administration. Data are expressed as a fold of expression of intracerebroventricularly administered saline. ${ }^{*} p<0.003$, samples are significantly different from saline samples by two-tailed $t$ test $(n=4,3)$. Con, Control.

and VGF, $1.0 \pm 0.61 \mathrm{OD} / \mathrm{mm}^{2}$ normalized to $1.30 \pm 0.51$-fold of average control, $t_{(6)}=-0.596, p=0.573 ; \mathrm{LiCl}, 1.31 \pm 0.68$ $\mathrm{OD} / \mathrm{mm}^{2}$ normalized to $1.99 \pm 0.59$-fold of average control, $t_{(6)}=$ $-1.679, p=0.144$ ) and $\beta$-catenin (control, $0.86 \pm 0.10 \mathrm{OD} /$ $\mathrm{mm}^{2}$ and VGF, $0.86 \pm 0.19 \mathrm{OD} / \mathrm{mm}^{2}$ normalized to $0.99 \pm$ 0.16 -fold of average control, $t_{(5)}=0.057, p=0.957$; LiCl, $0.83 \pm$ $0.11 \mathrm{OD} / \mathrm{mm}^{2}$ normalized to $1.08 \pm 0.15$-fold of average control, $\left.t_{(5)}=-0.644, p=0.548\right)$. Insufficient inactivation of GSK proteins may contribute to this result because GSK3 $\alpha$ is activated subsequently to GSK3 $\beta$. Also, $\beta$-catenin tends to translocate and accumulate in the nucleus (Takahashi-Yanaga and Sasaguri, 2007 ), and therefore measuring $\beta$-catenin levels in a whole-cell lysate may not be adequate. In general, the actions of VGF mimic those of LiCl by activating the same second-messenger signaling pathways.

We have also demonstrated that chronic (21 d) intracerebroventricularly administered VGF in vivo induced phosphorylation of the same signaling molecules as in vitro relative to intracere- 
broventricularly administered saline (Fig. 7C): p42 MAPK (saline, $2.05 \pm 0.27 \mathrm{OD} /$ $\mathrm{mm}^{2}$ and VGF, $2.77 \pm 0.11 \mathrm{OD} / \mathrm{mm}^{2}$ normalized to $1.35 \pm 0.06$-fold of average saline, $t_{(5)}=-6.847, p=0.001$ ), Akt (saline, $0.75 \pm 0.05 \mathrm{OD} / \mathrm{mm}^{2}$ and VGF, $1.10 \pm 0.07 \mathrm{OD} / \mathrm{mm}^{2}$ normalized to $1.48 \pm 0.11$-fold of average saline, $t_{(5)}=$ $-5.333, p=0.003$ ), and GSK3 $\beta$ (saline, $1.42 \pm 0.33 \mathrm{OD} / \mathrm{mm}^{2}$ and VGF, $2.17 \pm$ $0.28 \mathrm{OD} / \mathrm{mm}^{2}$ normalized to $1.68 \pm$ 0.152 -fold of average saline, $t_{(5)}=$ $-5.359, p=0.003$ ) but not GSK $\alpha$ (saline, $0.68 \pm 0.13 \mathrm{OD} / \mathrm{mm}^{2}$ and VGF, $0.76 \pm$ $0.11 \mathrm{OD} / \mathrm{mm}^{2}$ normalized to $1.11 \pm 0.19$ fold of average saline, $t_{(5)}=-0.672, p=$ 0.531).

Finally, we examined whether VGF is required for the activation of signaling molecules by $\mathrm{LiCl}$ by subjecting WT and $V G F^{+/-}$mice to chronic (21 d) LiCl injections intraperitoneally (Fig. 8). Saline injections administered intraperitoneally into WT mice were used as a control, and statistics was performed on data normalized to saline controls by ANOVA. Statistics reported are for $\mathrm{LiCl}$ in WT mice compared with saline in WT mice and $\mathrm{LiCl}$ in $\mathrm{VGF}^{+/-}$mice compared with $\mathrm{LiCl}$ in WT mice. Lithium increased phosphorylation of $\mathrm{p} 42 \mathrm{MAPK}$ in WT mice relative to saline, and the effect of $\mathrm{LiCl}$ was blocked in $V G F^{+/-}$mice (saline, $0.45 \pm 0.04 \mathrm{OD} / \mathrm{mm}^{2}$ and $\mathrm{LiCl} \mathrm{WT}, 0.72 \pm 0.11 \mathrm{OD} / \mathrm{mm}^{2}$ normalized to $1.59 \pm 023, F_{(2,6)}=4.800$, Fisher's $p=0.0402 ; \mathrm{LiCl}$ $V G F^{+/-}, 0.44 \pm 0.07 \mathrm{OD} / \mathrm{mm}^{2}$ normalized to $0.97 \pm 0.015, F_{(2,6)}=$ 4.800 , Fisher's $p=0.0332)$. Similarly, LiCl significantly induced phospho-Akt in WT mice, which was prevented in $V G F^{+/-}$mice (saline, $0.63 \pm 0.12 \mathrm{OD} / \mathrm{mm}^{2}$ and $\mathrm{LiCl} \mathrm{WT}, 0.85 \pm 0.21 \mathrm{OD} /$ $\mathrm{mm}^{2}$ normalized to $1.65 \pm 0.24, F_{(2,6)}=9.669$, Fisher's $p=$ 0.0070; $\mathrm{LiCl} V G F^{+/-}, 0.79 \pm 0.03 \mathrm{OD} / \mathrm{mm}^{2}$ normalized to $1.26 \pm 0.05 \mathrm{LiCl}, F_{(2,6)}=9.669$, Fisher's $\left.p=0.0442\right)$. PhosphoGSK $\alpha$ was enhanced by $\mathrm{LiCl}$ in WT and was not reduced in $V G F^{+/-}$mice (saline, $2.06 \pm 0.42 \mathrm{OD} / \mathrm{mm}^{2}$ and $\mathrm{LiCl} \mathrm{WT}, 2.58 \pm$ $0.59 \mathrm{OD} / \mathrm{mm}^{2}$ normalized to $1.54 \pm 0.02, F_{(2,6)}=11.111$, Fisher's $p=0.0111$; $\mathrm{LiCl} V G F^{+/-} 3.09 \pm 0.28 \mathrm{OD} / \mathrm{mm}^{2}$ normalized to $1.50 \pm 0.14 \mathrm{LiCl}, F_{(2,6)}=11.111$, Fisher's $\left.p=0.7979\right)$. Phospho-GSK $3 \beta$ was increased by $\mathrm{LiCl}$ in WT mice, and, although there was less phosphorylation in $\mathrm{VGF}^{+/-}$mice, it was not significantly different from LiCl-treated WT mice (saline, $0.17 \pm 0.02 \mathrm{OD} / \mathrm{mm}^{2}$ and $\mathrm{LiCl} \mathrm{WT}, 0.25 \pm 0.03 \mathrm{OD} / \mathrm{mm}^{2}$ normalized to $1.47 \pm 0.16, F_{(2,6)}=4.841$, Fisher's $p=0.0233 ; \mathrm{LiCl}$ $V G F^{+/-}, 0.19 \pm 0.02 \mathrm{OD} / \mathrm{mm}^{2}$ normalized to $1.13 \pm 0.11 \mathrm{LiCl}$, $F_{(2,6)}=4.841$, Fisher's $\left.p=0.0747\right)$. These findings suggest that $V G F$ is necessary for the LiCl-induced activation of MAPK and Akt and that it might be involved in the phosphorylation of GSK3 $\beta$. Together, our findings suggest a role for the neuropeptide VGF in the pathogenesis of affective disorders via a mechanism similar to $\mathrm{LiCl}$.

\section{Discussion}

VGF mRNA is reduced in human bipolar postmortem brains We found a region-specific expression of VGF in human postmortem brains. In the hippocampus and prefrontal cortex, the widespread VGF mRNA expression patterns we observed in hu- mans are similar to those in the rodent (Snyder and Salton, 1998), which suggests that VGF may have a fundamental and conserved evolutionary role. Within the CA area, we observed significantly reduced VGF expression in the CAlb subregion in brains from bipolar disorder patients. CA1 represents the final common pathway for the output of the excitatory activity from the trisynaptic pathway. Additionally, there are reports associating alterations in CA1 gene expression, morphology, and function with bipolar disorder and other psychiatric disorders (Hammonds and Shim, 2009; Schobel et al., 2009). We also observed a significant decrease in the CA2 subregion in subjects with bipolar disorder. CA2 is an important information processing point between the dentate gyrus and the subiculum (Heckers et al., 2002). CA2 has also been implicated in psychiatric disorders (Benes et al., 2001; Knable et al., 2004; Dean et al., 2005), and, in particular, studies suggest a dysfunction of CA2 inhibitory GABAergic interneurons in severe mental illness (Müller et al., 2001; Tian et al., 2007; Guilarte et al., 2008). Our findings of reduced VGF expression in CA2 pyramidal cells of bipolar disorder patients suggest that, in addition to the alterations in inhibitory interneurons, there may be changes in the function of excitatory neurons.

In the human DLPFC, we detected reduced VGF mRNA levels in the BA9 region in bipolar disorder patients. Other studies have demonstrated changes in gene expression patterns in BA9 in psychiatric disorders (Digney et al., 2005; Veldic et al., 2005; Guilarte et al., 2008). Within BA9, we detected diminished VGF in layer VI. Cells in layer VI project to the thalamus and are essential for relaying cortical signals to other brain regions. Thus, our finding of reduced VGF expression in layer VI suggests that there may be deficits in communication between the DLPFC and the rest of the nervous system.

Our findings are consistent with the SMRI Genomics Database, and we demonstrate for the first time the detailed expression pattern in bipolar disorder. The reported upregulation of 
VGF in the CSF of subjects with schizophrenia (Huang et al., 2006) may be explained by the differential kinetics of mRNA versus peptide metabolites in the CSF or by differences in the disease population. Consistent with our findings, a VGF peptide was reported to be decreased in CSF in neurodegenerative diseases (Ranganathan et al., 2005; Rüetschi et al., 2005; Selle et al., 2005; Zhao et al., 2008). VGF levels are also downregulated in leukocytes of depressed patients but are restored in response to antidepressant treatment (Cattaneo et al., 2010). The usefulness of VGF as a biomarker for bipolar disorder and other neurological diseases should be explored in future studies.

\section{VGF contributes to some of the behavioral effects of lithium}

This study establishes a functional role for VGF in both the depressive and manic phase of bipolar disorder using behavioral models. Recently, we and others demonstrated the antidepressant-like actions of VGF (Hunsberger et al., 2007; Thakker-Varia et al., 2007). However, the behavioral procedures used in those studies respond only to acute antidepressant treatment. We now demonstrate that chronic VGF is effective in novelty-induced hypophagia, which is only sensitive to the effects of chronic antidepressant treatment (Cryan and Holmes, 2005; Dulawa and Hen, 2005). This time course is consistent with typical response of the depressive phase of bipolar disorder to antidepressants (Bowden, 2005; Trivedi, 2006). Lithium has been found to be effective in the forced-swim test (FST), tailsuspension test (TST), and amphetamine procedures (O'Brien et al., 2004; Bersudsky et al., 2007; Cryns et al., 2007; Gould et al., 2007), but our study is the first to document effectiveness of chronic doses of lithium in novelty-induced hypophagia.

Novelty-induced hypophagia has been shown to be sensitive to acute effects of benzodiazepines in addition to chronic antidepressants, and therefore anxiolytic-like effects cannot be ruled out. However, acute administration of VGF does not affect anxiety-related behavior in other paradigms. In addition, there are no differences in normal anxiety levels in elevated-plus-maze and open-field tests in $V G F^{+/-}$mice, but there are deficits in the depression paradigms FST and TST (Hunsberger et al., 2007). Finally, the response to chronic antidepressants in the noveltyinduced hypophagia test has been shown to be associated with neurogenesis at least in some mouse strains (Balu et al., 2009), which is suggestive of an antidepressant-like effect because antidepressants but not anxiolytics have been shown to increase neurogenesis.

The fact that $\mathrm{LiCl}$ and DMI in $V G F^{+/-}$mutant mice did not significantly reduce latency to drink in the novel environment relative to saline suggests that $V G F$ may contribute to the effects of $\mathrm{LiCl}$ and DMI. However, because $V G F^{+/-}$mice were not significantly different from WT mice treated with $\mathrm{LiCl}$ and DMI, it is possible that normal levels of VGF may not be absolutely necessary for the actions of the antidepressant. Alternatively, the VGF heterozygous mice may have sufficient levels of VGF to contribute to the actions of the antidepressant. Our results using this procedure cannot be attributed to changes in appetitive behavior. Although genetic ablation of VGF results in hypermetabolism, the lean phenotype in $V G F^{+/-}$mice is based on increased metabolic activity rather than decreased feeding (Hahm et al., 1999, 2002). Moreover, because novelty-induced hypophagia does not rely on food deprivation, there is no concern that feeding behavior might interfere with the results.

We also used amphetamine-induced hyperactivity to phenocopy manic-like behavior, which is a valid assay for this study because the use of dopaminergic stimulants has been associated with the onset of mania in bipolar disorder patients and with manic-like symptoms in control subjects (Peet and Peters, 1995; Anand et al., 2000). Furthermore, studies report that lithium can attenuate or prevent the behavioral and/or functional effects of dopaminergic drugs in humans (Bell et al., 2005; Willson et al., 2005). Administration of amphetamine in rodents result in behavioral changes and treatment responses that are similar to bipolar disorder and therefore satisfy face and predictive validity. With regard to construct validity, however, it is possible that the use of amphetamine could be viewed mechanistically as a model of drug abuse or addiction rather than bipolar disorder (Kato et al., 2007). Despite this caveat, amphetamine-induced hyperactivity has been used frequently to phenocopy manic-like behavior and test novel lithium-mimetic compounds (Frey et al., 2006; Gould et al., 2007; Shaldubina et al., 2007; Du et al., 2008; Shaltiel et al., 2008).

The fact that VGF reduced hyperlocomotion in a dosedependent manner in response to amphetamine indicates that VGF has novel effects attenuating manic-like behavior, similar to the effects seen with LiCl treatment. VGF injections into the hippocampus do not affect baseline locomotor behavior, and $V G F^{+l-}$ mice do not have altered locomotor activity (Fig. 6B) (Hunsberger et al., 2007). Therefore, the effects of VGF are specific to the response to amphetamine. In the amphetamineinduced hyperactivity procedure, reduced levels of VGF result in enhanced response to amphetamine injection, suggesting that endogenous $V G F$ is necessary for attenuating the normal response to amphetamine. We do not believe that the enhanced susceptibility to the locomotor stimulating effects of amphetamine seen in $V G F^{+/-}$mice is attributable to the fact that $V G F$ mutant mice show hypermetabolism. However, we cannot absolutely rule out the possibility that $V G F^{+/-}$mice have elevated baseline levels of plasma or brain amphetamine. In summary, our results suggest a potential mood-stabilizing activity for VGF similar to lithium.

\section{VGF contributes to some of the molecular effects of lithium}

Our findings demonstrate that two distinct molecules with similar effects in behavioral studies, $\mathrm{LiCl}$ and VGF, stimulate the extracellular signal-regulated kinase (ERK) pathway and Aktmediated GSK phosphorylation in the hippocampus, which is implicated in mood modulation. Both lithium and valproate, which is also used to treat bipolar disorder, stimulate the ERK/ MAPK pathway, and ERK may be required for the behavioral effects of LiCl (Einat et al., 2003). Lithium also increases Aktmediated phosphorylation of GSK3 $\beta$, which inhibits the activity of the enzyme. Altered levels of GSK $3 \beta$ and its target $\beta$-catenin are associated with various neuropsychiatric disorders and neuropsychiatric drugs (Wada, 2009). Moreover, GSK3 $\beta$ inhibitors have been shown to have antidepressant and anti-manic-like activity (Kaidanovich-Beilin et al., 2004; O’Brien et al., 2004; Gould et al., 2006).

A previous study demonstrated that expression of an adapter protein, Grb2, involved in MAPK/ERK cascade is induced by VGF (Hunsberger et al., 2007), supporting our findings. Recently, VGF peptides were shown to activate MAPK p38 in microglia in a model of peripheral nerve injury (Riedl et al., 2009), suggesting that there are other pathways stimulated by VGF that remain to be examined in the CNS. We have shown that VGF is required for the activation of several signaling molecules by $\mathrm{LiCl}$, including MAPK and Akt and possibly GSK3 $\beta$, suggesting that VGF may be downstream of $\mathrm{LiCl}$ pathways. The behavioral and intracellular cell signaling data strongly suggest that the ERK and Akt-GSK pathways may be common targets of molecules such as 
$\mathrm{LiCl}$ and VGF that have potential antidepressant-like and antimanic effects in animals.

The altered metabolic activity and smaller hippocampal and DLPFC volumes associated with mood disorders may result in part from reduced VGF levels because VGF enhances both neuronal activity (Alder et al., 2003; Bozdagi et al., 2008) and neurogenesis in the hippocampus (Thakker-Varia et al., 2007). Moreover, VGF may have antidepressant-like actions through altering synaptic activity and/or neurogenesis (Malberg and Monteggia, 2008; Thakker-Varia and Alder, 2009). Understanding the molecular and cellular changes that underlie the actions of neuropeptides such as VGF and how these adaptations result in antidepressant-like effects will aid in developing drugs that target novel pathways for psychiatric disorders.

\section{References}

Alder J, Thakker-Varia S, Bangasser DA, Kuroiwa M, Plummer MR, Shors TJ, Black IB (2003) Brain-derived neurotrophic factor-induced gene expression reveals novel actions of VGF in hippocampal synaptic plasticity. J Neurosci 23:10800-10808.

Altar CA, Laeng P, Jurata LW, Brockman JA, Lemire A, Bullard J, Bukhman YV, Young TA, Charles V, Palfreyman MG (2004) Electroconvulsive seizures regulate gene expression of distinct neurotrophic signaling pathways. J Neurosci 24:2667-2677.

Altshuler L, Bookheimer S, Townsend J, Proenza MA, Sabb F, Mintz J, Cohen MS (2008) Regional brain changes in bipolar I depression: a functional magnetic resonance imaging study. Bipolar Disord 10:708-717.

Anand A, Verhoeff P, Seneca N, Zoghbi SS, Seibyl JP, Charney DS, Innis RB (2000) Brain SPECT imaging of amphetamine-induced dopamine release in euthymic bipolar disorder patients. Am J Psychiatry 157:1108-1114.

Aubry JM, Schwald M, Ballmann E, Karege F (2009) Early effects of mood stabilizers on the Akt/GSK-3beta signaling pathway and on cell survival and proliferation. Psychopharmacology (Berl) 205:419-429.

Balu DT, Hodes GE, Anderson BT, Lucki I (2009) Enhanced sensitivity of the MRL/MpJ mouse to the neuroplastic and behavioral effects of chronic antidepressant treatments. Neuropsychopharmacology 34:1764-1773.

Bartolomucci A, Rigamonti AE, Bulgarelli I, Torsello A, Locatelli V, Pavone F, Levi A, Possenti R, Muller EE, Moles A (2007) Chronic intracerebroventricular TLQP-21 delivery does not modulate the GH/IGF-1-axis and muscle strength in mice. Growth Horm IGF Res 17:342-345.

Beaulieu JM, Sotnikova TD, Yao WD, Kockeritz L, Woodgett JR, Gainetdinov RR, Caron MG (2004) Lithium antagonizes dopamine-dependent behaviors mediated by an AKT/glycogen synthase kinase 3 signaling cascade. Proc Natl Acad Sci U S A 101:5099-5104.

Bell EC, Willson MC, Wilman AH, Dave S, Asghar SJ, Silverstone PH (2005) Lithium and valproate attenuate dextroamphetamine-induced changes in brain activation. Hum Psychopharmacol 20:87-96.

Benes FM, Todtenkopf MS, Kostoulakos P (2001) GluR5,6,7 subunit immunoreactivity on apical pyramidal cell dendrites in hippocampus of schizophrenics and manic depressives. Hippocampus 11:482-491.

Bersudsky Y, Shaldubina A, Belmaker RH (2007) Lithium's effect in forcedswim test is blood level dependent but not dependent on weight loss. Behav Pharmacol 18:77-80.

Bonilha L, Molnar C, Horner MD, Anderson B, Forster L, George MS, Nahas Z (2008) Neurocognitive deficits and prefrontal cortical atrophy in patients with schizophrenia. Schizophr Res 101:142-151.

Bonni A, Ginty DD, Dudek H, Greenberg ME (1995) Serine 133phosphorylated CREB induces transcription via a cooperative mechanism that may confer specificity to neurotrophin signals. Mol Cell Neurosci 6:168-183.

Bowden CL (2005) Treatment options for bipolar depression. J Clin Psychiatry 66 [Suppl 1]:S3-S6.

Bozdagi O, Rich E, Tronel S, Sadahiro M, Patterson K, Shapiro ML, Alberini CM, Huntley GW, Salton SR (2008) The neurotrophin-inducible gene Vgf regulates hippocampal function and behavior through a brainderived neurotrophic factor-dependent mechanism. J Neurosci 28:9857-9869.

Cattaneo A, Sesta A, Calabrese F, Nielsen G, Riva MA, Gennarelli M (2010) The expression of VGF is reduced in leukocytes of depressed patients and it is restored by effective antidepressant treatment. Neuropsychopharmacology 35:1423-1428.

Cryan JF, Holmes A (2005) The ascent of mouse: advances in modelling human depression and anxiety. Nat Rev Drug Discov 4:775-790.

Cryns K, Shamir A, Shapiro J, Daneels G, Goris I, Van Craenendonck H, Straetemans R, Belmaker RH, Agam G, Moechars D, Steckler T (2007) Lack of lithium-like behavioral and molecular effects in IMPA2 knockout mice. Neuropsychopharmacology 32:881-891.

Dean B, Scarr E, McLeod M (2005) Changes in hippocampal GABAA receptor subunit composition in bipolar 1 disorder. Brain Res Mol Brain Res 138:145-155.

Dickstein DP, Milham MP, Nugent AC, Drevets WC, Charney DS, Pine DS, Leibenluft E (2005) Frontotemporal alterations in pediatric bipolar disorder: results of a voxel-based morphometry study. Arch Gen Psychiatry 62:734-741.

Digney A, Keriakous D, Scarr E, Thomas E, Dean B (2005) Differential changes in apolipoprotein $\mathrm{E}$ in schizophrenia and bipolar I disorder. Biol Psychiatry 57:711-715.

Drevets WC (2001) Neuroimaging and neuropathological studies of depression: implications for the cognitive-emotional features of mood disorders. Curr Opin Neurobiol 11:240-249.

Du J, Creson TK, Wu LJ, Ren M, Gray NA, Falke C, Wei Y, Wang Y, Blumenthal R, Machado-Vieira R, Yuan P, Chen G, Zhuo M, Manji HK (2008) The role of hippocampal GluR1 and GluR2 receptors in manic-like behavior. J Neurosci 28:68-79.

Dulawa SC, Hen R (2005) Recent advances in animal models of chronic antidepressant effects: the novelty-induced hypophagia test. Neurosci Biobehav Rev 29:771-783.

Dulawa SC, Holick KA, Gundersen B, Hen R (2004) Effects of chronic fluoxetine in animal models of anxiety and depression. Neuropsychopharmacology 29:1321-1330.

Eagleson KL, Fairfull LD, Salton SR, Levitt P (2001) Regional differences in neurotrophin availability regulate selective expression of VGF in the developing limbic cortex. J Neurosci 21:9315-9324.

Einat H, Yuan P, Gould TD, Li J, Du J, Zhang L, Manji HK, Chen G (2003) The role of the extracellular signal-regulated kinase signaling pathway in mood modulation. J Neurosci 23:7311-7316.

Frey BN, Andreazza AC, Ceresér KM, Martins MR, Valvassori SS, Réus GZ, Quevedo J, Kapczinski F (2006) Effects of mood stabilizers on hippocampus BDNF levels in an animal model of mania. Life Sci 79:281-286.

Fusar-Poli P, Perez J, Broome M, Borgwardt S, Placentino A, Caverzasi E, Cortesi M, Veggiotti P, Politi P, Barale F, McGuire P (2007) Neurofunctional correlates of vulnerability to psychosis: a systematic review and meta-analysis. Neurosci Biobehav Rev 31:465-484.

Gould TD, Picchini AM, Einat H, Manji HK (2006) Targeting glycogen synthase kinase- 3 in the CNS: implications for the development of new treatments for mood disorders. Curr Drug Targets 7:1399-1409.

Gould TD, O’Donnell KC, Picchini AM, Manji HK (2007) Strain differences in lithium attenuation of d-amphetamine-induced hyperlocomotion: a mouse model for the genetics of clinical response to lithium. Neuropsychopharmacology 32:1321-1333.

Guilarte TR, Hammoud DA, McGlothan JL, Caffo BS, Foss CA, Kozikowski AP, Pomper MG (2008) Dysregulation of glutamate carboxypeptidase II in psychiatric disease. Schizophr Res 99:324-332.

Gur TL, Conti AC, Holden J, Bechtholt AJ, Hill TE, Lucki I, Malberg JE, Blendy JA (2007) cAMP response element-binding protein deficiency allows for increased neurogenesis and a rapid onset of antidepressant response. J Neurosci 27:7860-7868.

Hagg T, Baker KA, Emsley JG, Tetzlaff W (2005) Prolonged local neurotrophin-3 infusion reduces ipsilateral collateral sprouting of spared corticospinal axons in adult rats. Neuroscience 130:875-887.

Hahm S, Mizuno TM, Wu TJ, Wisor JP, Priest CA, Kozak CA, Boozer CN, Peng B, McEvoy RC, Good P, Kelley KA, Takahashi JS, Pintar JE, Roberts JL, Mobbs CV, Salton SR (1999) Targeted deletion of the Vgf gene indicates that the encoded secretory peptide precursor plays a novel role in the regulation of energy balance. Neuron 23:537-548.

Hahm S, Fekete C, Mizuno TM, Windsor J, Yan H, Boozer CN, Lee C, Elmquist JK, Lechan RM, Mobbs CV, Salton SR (2002) VGF is required for obesity induced by diet, gold thioglucose treatment, and agouti and is differentially regulated in pro-opiomelanocortin- and neuropeptide Y-containing arcuate neurons in response to fasting. J Neurosci 22:6929-6938. 
Hammonds MD, Shim SS (2009) Effects of 4-week treatment with lithium and olanzapine on levels of brain-derived neurotrophic factor, B-cell CLL/lymphoma 2 and phosphorylated cyclic adenosine monophosphate response element-binding protein in the sub-regions of the hippocampus. Basic Clin Pharmacol Toxicol 105:113-119.

Heckers S, Stone D, Walsh J, Shick J, Koul P, Benes FM (2002) Differential hippocampal expression of glutamic acid decarboxylase 65 and 67 messenger RNA in bipolar disorder and schizophrenia. Arch Gen Psychiatry 59:521-529.

Huang JT, Leweke FM, Oxley D, Wang L, Harris N, Koethe D, Gerth CW, Nolden BM, Gross S, Schreiber D, Reed B, Bahn S (2006) Disease biomarkers in cerebrospinal fluid of patients with first-onset psychosis. PLoS Med 3:e428.

Hunsberger JG, Newton SS, Bennett AH, Duman CH, Russell DS, Salton SR, Duman RS (2007) Antidepressant actions of the exercise-regulated gene VGF. Nat Med 13:1476-1482.

Kaidanovich-Beilin O, Milman A, Weizman A, Pick CG, Eldar-Finkelman H (2004) Rapid antidepressive-like activity of specific glycogen synthase kinase-3 inhibitor and its effect on beta-catenin in mouse hippocampus. Biol Psychiatry 55:781-784.

Kato T, Kubota M, Kasahara T (2007) Animal models of bipolar disorder. Neurosci Biobehav Rev 31:832-842.

Kesner RP (2007) Behavioral functions of the CA3 subregion of the hippocampus. Learn Mem 14:771-781.

Knable MB, Barci BM, Webster MJ, Meador-Woodruff J, Torrey EF (2004) Molecular abnormalities of the hippocampus in severe psychiatric illness: postmortem findings from the Stanley Neuropathology Consortium. Mol Psychiatry 9:609-620, 544.

Koenigsberg HW, Siever LJ, Lee H, Pizzarello S, New AS, Goodman M, Cheng H, Flory J, Prohovnik I (2009) Neural correlates of emotion processing in borderline personality disorder. Psychiatry Res 172:192-199.

Larsen PJ, Vrang N, Petersen PC, Kristensen P (2000) Chronic intracerebroventricular administration of recombinant CART(42-89) peptide inhibits and causes weight loss in lean and obese Zucker (fa/fa) rats. Obes Res 8:590-596.

Liang MH, Wendland JR, Chuang DM (2008) Lithium inhibits Smad3/4 transactivation via increased CREB activity induced by enhanced PKA and AKT signaling. Mol Cell Neurosci 37:440-453.

Lorente de Nó R (1934) Studies on structure of the cerebral cortex. Continuation of the study of the ammonic system. Psychol Neurol 46:113-117.

Malberg JE, Monteggia LM (2008) VGF, a new player in antidepressant action? Sci Signal 1:pe19.

Malhi GS, Adams D, Cahill CM, Dodd S, Berk M (2009) The management of individuals with bipolar disorder: a review of the evidence and its integration into clinical practice. Drugs 69:2063-2101.

Manji HK, Duman RS (2001) Impairments of neuroplasticity and cellular resilience in severe mood disorders: implications for the development of novel therapeutics. Psychopharmacol Bull 35:5-49.

Mayberg HS, Brannan SK, Tekell JL, Silva JA, Mahurin RK, McGinnis S, Jerabek PA (2000) Regional metabolic effects of fluoxetine in major depression: serial changes and relationship to clinical response. Biol Psychiatry $48: 830-843$.

Melcher T, Falkai P, Gruber O (2008) Functional brain abnormalities in psychiatric disorders: neural mechanisms to detect and resolve cognitive conflict and interference. Brain Res Rev 59:96-124.

Müller MB, Lucassen PJ, Yassouridis A, Hoogendijk WJ, Holsboer F, Swaab DF (2001) Neither major depression nor glucocorticoid treatment affects the cellular integrity of the human hippocampus. Eur J Neurosci 14:1603-1612.

Nakatani N, Hattori E, Ohnishi T, Dean B, Iwayama Y, Matsumoto I, Kato T, Osumi N, Higuchi T, Niwa S, Yoshikawa T (2006) Genome-wide expression analysis detects eight genes with robust alterations specific to bipolar I disorder: relevance to neuronal network perturbation. Hum Mol Genet 15:1949-1962.

Newton SS, Collier EF, Hunsberger J, Adams D, Terwilliger R, Selvanayagam E, Duman RS (2003) Gene profile of electroconvulsive seizures: induction of neurotrophic and angiogenic factors. J Neurosci 23:10841-10851.

O'Brien WT, Harper AD, Jové F, Woodgett JR, Maretto S, Piccolo S, Klein PS (2004) Glycogen synthase kinase-3beta haploinsufficiency mimics the behavioral and molecular effects of lithium. J Neurosci 24:6791-6798.

O'Donnell KC, Gould TD (2007) The behavioral actions of lithium in ro- dent models: leads to develop novel therapeutics. Neurosci Biobehav Rev 31:932-962.

Peet M, Peters S (1995) Drug-induced mania. Drug Saf 12:146-153.

Poncelet M, Dangoumau L, Soubrie P, Simon P (1987) Effects of neuroleptic drugs, clonidine and lithium on the expression of conditioned behavioral excitation in rats. Psychopharmacology (Berl) 92:393-397.

R Development Core Team (2009) A language and environment for statistical computing. Vienna: R Foundation for Statistical Computing.

Rajkowska G, Goldman-Rakic PS (1995a) Cytoarchitectonic definition of prefrontal areas in the normal human cortex. I. Remapping of areas 9 and 46 using quantitative criteria. Cereb Cortex 5:307-322.

Rajkowska G, Goldman-Rakic PS (1995b) Cytoarchitectonic definition of prefrontal areas in the normal human cortex. II. Variability in locations of areas 9 and 46 and relationship to the Talairach Coordinate System. Cereb Cortex 5:323-337.

Ranganathan S, Williams E, Ganchev P, Gopalakrishnan V, Lacomis D, Urbinelli L, Newhall K, Cudkowicz ME, Brown RH Jr, Bowser R (2005) Proteomic profiling of cerebrospinal fluid identifies biomarkers for amyotrophic lateral sclerosis. J Neurochem 95:1461-1471.

Riedl MS, Braun PD, Kitto KF, Roiko SA, Anderson LB, Honda CN, Fairbanks CA, Vulchanova L (2009) Proteomic analysis uncovers novel actions of the neurosecretory protein VGF in nociceptive processing. J Neurosci 29:13377-13388.

Royo NC, Conte V, Saatman KE, Shimizu S, Belfield CM, Soltesz KM, Davis JE, Fujimoto ST, McIntosh TK (2006) Hippocampal vulnerability following traumatic brain injury: a potential role for neurotrophin- $4 / 5$ in pyramidal cell neuroprotection. Eur J Neurosci 23:1089-1102.

Rüetschi U, Zetterberg H, Podust VN, Gottfries J, Li S, Hviid Simonsen A, McGuire J, Karlsson M, Rymo L, Davies H, Minthon L, Blennow K (2005) Identification of CSF biomarkers for frontotemporal dementia using SELDI-TOF. Exp Neurol 196:273-281.

Sahu A (2002) Resistance to the satiety action of leptin following chronic central leptin infusion is associated with the development of leptin resistance in neuropeptide Y neurones. J Neuroendocrinol 14:796-804.

Schobel SA, Lewandowski NM, Corcoran CM, Moore H, Brown T, Malaspina D, Small SA (2009) Differential targeting of the CA1 subfield of the hippocampal formation by schizophrenia and related psychotic disorders. Arch Gen Psychiatry 66:938-946.

Selle H, Lamerz J, Buerger K, Dessauer A, Hager K, Hampel H, Karl J, Kellmann M, Lannfelt L, Louhija J, Riepe M, Rollinger W, Tumani H, Schrader M, Zucht HD (2005) Identification of novel biomarker candidates by differential peptidomics analysis of cerebrospinal fluid in Alzheimer's disease. Comb Chem High Throughput Screen 8:801-806.

Shaldubina A, Buccafusca R, Johanson RA, Agam G, Belmaker RH, Berry GT, Bersudsky Y (2007) Behavioural phenotyping of sodium-myo-inositol cotransporter heterozygous knockout mice with reduced brain inositol. Genes Brain Behav 6:253-259.

Shaltiel G, Maeng S, Malkesman O, Pearson B, Schloesser RJ, Tragon T, Rogawski M, Gasior M, Luckenbaugh D, Chen G, Manji HK (2008) Evidence for the involvement of the kainate receptor subunit GluR6 (GRIK2) in mediating behavioral displays related to behavioral symptoms of mania. Mol Psychiatry 13:858-872.

Sheline YI, Wang PW, Gado MH, Csernansky JG, Vannier MW (1996) Hippocampal atrophy in recurrent major depression. Proc Natl Acad Sci U S A 93:3908-3913.

Shibayama M, Hattori S, Himes BT, Murray M, Tessler A (1998) Neurotrophin-3 prevents death of axotomized Clarke's nucleus neurons in adult rat. J Comp Neurol 390:102-111.

Siuciak JA, Lewis DR, Wiegand SJ, Lindsay RM (1997) Antidepressant-like effect of brain-derived neurotrophic factor (BDNF). Pharmacol Biochem Behav 56:131-137.

Snyder SE, Salton SR (1998) Expression of VGF mRNA in the adult rat central nervous system. J Comp Neurol 394:91-105.

Takahashi-Yanaga F, Sasaguri T (2007) The Wnt/beta-catenin signaling pathway as a target in drug discovery. J Pharmacol Sci 104:293-302.

Takigawa M, Fukuzako H, Ueyama K, Tominaga H (1994) Intracranial selfstimulation and locomotor traces as indicators for evaluating and developing antipsychotic drugs. Jpn J Psychiatry Neurol 48:127-132.

Thakker-Varia S, Alder J (2009) Neuropeptides in depression: role of VGF. Behav Brain Res 197:262-278.

Thakker-Varia S, Alder J, Crozier RA, Plummer MR, Black IB (2001) Rab3A is required for brain-derived neurotrophic factor-induced synaptic plas- 
ticity: transcriptional analysis at the population and single-cell levels. J Neurosci 21:6782-6790.

Thakker-Varia S, Krol JJ, Nettleton J, Bilimoria PM, Bangasser DA, Shors TJ, Black IB, Alder J (2007) The neuropeptide VGF produces antidepressantlike behavioral effects and enhances proliferation in the hippocampus. J Neurosci 27:12156-12167.

Tian SY, Wang JF, Bezchlibnyk YB, Young LT (2007) Immunoreactivity of $43 \mathrm{kDa}$ growth-associated protein is decreased in post mortem hippocampus of bipolar disorder and schizophrenia. Neurosci Lett 411:123-127.

Torrey EF, Webster M, Knable M, Johnston N, Yolken RH (2000) The Stanley Foundation brain collection and neuropathology consortium. Schizophr Res 44:151-155.

Trivedi MH (2006) Major depressive disorder: remission of associated symptoms. J Clin Psychiatry 67 [Suppl 6]:S27-S32.

Ullal GR, Michalski B, Xu B, Racine RJ, Fahnestock M (2007) NT-3 modulates BDNF and proBDNF levels in naive and kindled rat hippocampus. Neurochem Int 50:866-871.

Veldic M, Guidotti A, Maloku E, Davis JM, Costa E (2005) In psychosis, cortical interneurons overexpress DNA-methyltransferase 1. Proc Natl Acad Sci U S A 102:2152-2157.
Videbech P, Ravnkilde B (2004) Hippocampal volume and depression: a meta-analysis of MRI studies. Am J Psychiatry 161:1957-1966.

Wada A (2009) Lithium and neuropsychiatric therapeutics: neuroplasticity via glycogen synthase kinase-3beta, beta-catenin, and neurotrophin cascades. J Pharmacol Sci 110:14-28.

Weickert CS, Kittell DA, Saunders RC, Herman MM, Horlick RA, Kleinman JE, Hyde TM (2005) Basic fibroblast growth factor and fibroblast growth factor receptor-1 in the human hippocampal formation. Neuroscience 131:219-233.

Willson MC, Bell EC, Dave S, Asghar SJ, McGrath BM, Silverstone PH (2005) Valproate attenuates dextroamphetamine-induced subjective changes more than lithium. Eur Neuropsychopharmacol 15:633-639.

Woodside B, Beaulé C, Lauay C (2002) Chronic neuropeptide Y infusion during lactation suppresses pup growth and reduces the length of lactational infertility in rats. Horm Behav 41:59-69.

Zhao Z, Lange DJ, Ho L, Bonini S, Shao B, Salton SR, Thomas S, Pasinetti GM (2008) Vgf is a novel biomarker associated with muscle weakness in amyotrophic lateral sclerosis (ALS), with a potential role in disease pathogenesis. Int J Med Sci 5:92-99. 